\title{
The phytosociology, ecology, and plant diversity of new plant communities in Central Anatolia (Turkey)
}

\author{
Nihal Kenar ${ }^{1, *}$ (I) , Fatoş Şekerciler², Süleyman Çoban ${ }^{3}$ (1)
}

Key words: Aksaray, IranoTuranian, Niğde, steppe, plant community, riparian vegetation, syntaxonomy.

Ključne besede: Aksaray, iranoturanska, Niğde, stepa, rastlinska združba, obrečna vegetacija, sintaksonomija.
Received: 13. 2. 2019

Revision received: 20. 9. 2019

Accepted: 23. 9. 2019

\begin{abstract}
The Central Anatolian vegetation has diverse site conditions and small-scale plant diversity. For this reason, identification of plant communities is important for understanding their ecology and nature conservation. This study aims to contribute the syntaxonomical classification of the Central Anatolian vegetation. The study area is situated among Güzelyurt, Narköy, and Bozköy (Niğde) in the east of Aksaray province of Central Anatolia in Turkey. The vegetation data were collected using the phytosociological method of Braun-Blanquet and classified using TWINSPAN. The ecological characteristics of the units were investigated with Detrended Correspondence Analysis. Three new plant associations were described in the study. The steppe association was included in Onobrychido armenae-Thymetalia leucostomi and Astragalo microcephali-Brometea tomentelli. The forest-steppe association was classified under Quercion anatolicae in Quercetea pubescentis. The riparian association is the first poplar-dominated one described in Turkey and, classified under Alno glutinosae-Populetea albae and its alliance Populion albae.

Izvleček

Vegetacijo Srednje Anatolije najdemo na raznolikih rastiščih in je na majhnem območju vrstno zelo pestra. Identifikacija rastlinskih združb je zato pomembna za razumevanje njihove ekologije in naravovarstva. Raziskava je prispevek $\mathrm{k}$ sinataksonomski klasifikaciji vegetacije Srednje Anatolije. Preučevano območje obsega površino med mesti Güzelyurt, Narköy in Bozköy (Niğde) na vzhodu province Aksaray v Srednji Anatoliji v Turčiji. Vegetacijo smo preučevali s fitocenološko metodo po Braun-Blanquetu in klasificirali z metodo TWINSPAN. Ekološke značilnosti vegetacijskih tipov smo preučevali z Korespondenčno analizo z odstranjenim trendom (DCA). Opisali smo tri nove asociacije. Stepsko asociacijo smo vključili v red Onobrychido armenae-Thymetalia leucostomi in razred Astragalo microcephali-Brometea tomentelli. Gozdno-stepsko asociacijo smo uvrstili v zvezo Quercion anatolicae in razred Quercetea pubescentis. Obrečna vegetacija predstavlja prvo asociacijo, opisano v Turčiji, v kateri dominirajo topoli. Uvrstili smo jo v razred Alno glutinosae-Populetea albae in zvezo Populion albae.
\end{abstract}

1 Aksaray University, Faculty of Science and Letters, Department of Biology 68100, Aksaray, Turkey. E-mail: nkenar@aksaray.edu.tr

2 Ankara University, Faculty of Science, Department of Biology, 06100 Tandoğan, Ankara, Turkey.

3 Istanbul University-Cerrahpaşa, Faculty of Forestry, Department of Silviculture, 34473, Bahçeköy Sarıyer, İstanbul, Turkey.

* Corresponding author. 


\section{Introduction}

The vast plains of Central Anatolia, which is surrounded by high mountain ranges from the south and the north, and the Anatolian Diagonal from the east, are covered with steppe vegetation below 1000-1200 m a.s.l. Some volcanic mountains rise up almost $4000 \mathrm{~m}$ in the eastern part of the Inner Anatolia. The forest-steppes occur between 1200-2000 $\mathrm{m}$ a.s.l. of these mountains and the subalpine steppe vegetation also follows above this dry forest zone (Kurt et al. 2006, Atalay et al. 2014). Central Anatolia is also a very rich region in terms of wetlands which harbour many plant and animal species. Most of these wetlands are salty due to the location of the region in closed basins and evaporation more than precipitation (Langbein 1961, Seçmen \& Leblebici 1997). These areas are covered by halophytic vegetation dominated by the species of Salicornia L., Halocnemum M. Bieb, and Limonium Mill., while riparian and hydrophytic species, such as Salix L., Populus L., Schoenoplectus (Rchb.) Palla, Phragmites Adans., occur in non-saline habitats. The Cenral Anatolian steppe is dominated by cushion-forming plants such as Astragalus
L., Acantholimon L., Thymus L., Artemisia L., gramineous species, and dwarf shrubs under harsh continental climate, which is cold in winters and dry during summers with $300 \mathrm{~mm} /$ year precipitation, while the forest-steppes in the region are composed of xerophytic oaks such as Q. cerris L., Q. ithaburensis subsp. macrolepis (Kotschy) Hedge $\&$ Yalt., and Q. pubescens Willd., junipers (J. excelsa M. Bieb., J. foetidissima Willd.), and pine (P. nigra J.F. Arnold) (Kürschner \& Parolly 2012). The understory of the forest-steppes is rich in steppe species due to semi-open canopy, thus they have the mosaic-type aspect (Uğurlu et al. 2012). Further, the Central Anatolian steppes and forest-steppes host a high diversity of life-forms, rare, endemic, and threatened species due to their high structural heterogeneity and diverse topography (Kürschner \& Parolly 2012, Ambarli et al. 2016).

The steppes and forest-steppes are included in the Irano-Anatolian biodiversity hotspot in Turkey, which is one of the seven identified grassland hotspots of the Palearctic realm (Dengler et al. 2014, Ambarli et al. 2016). The number of species in the region is more than 2,000 and the endemism rate is about $30 \%$ which is a remarkably

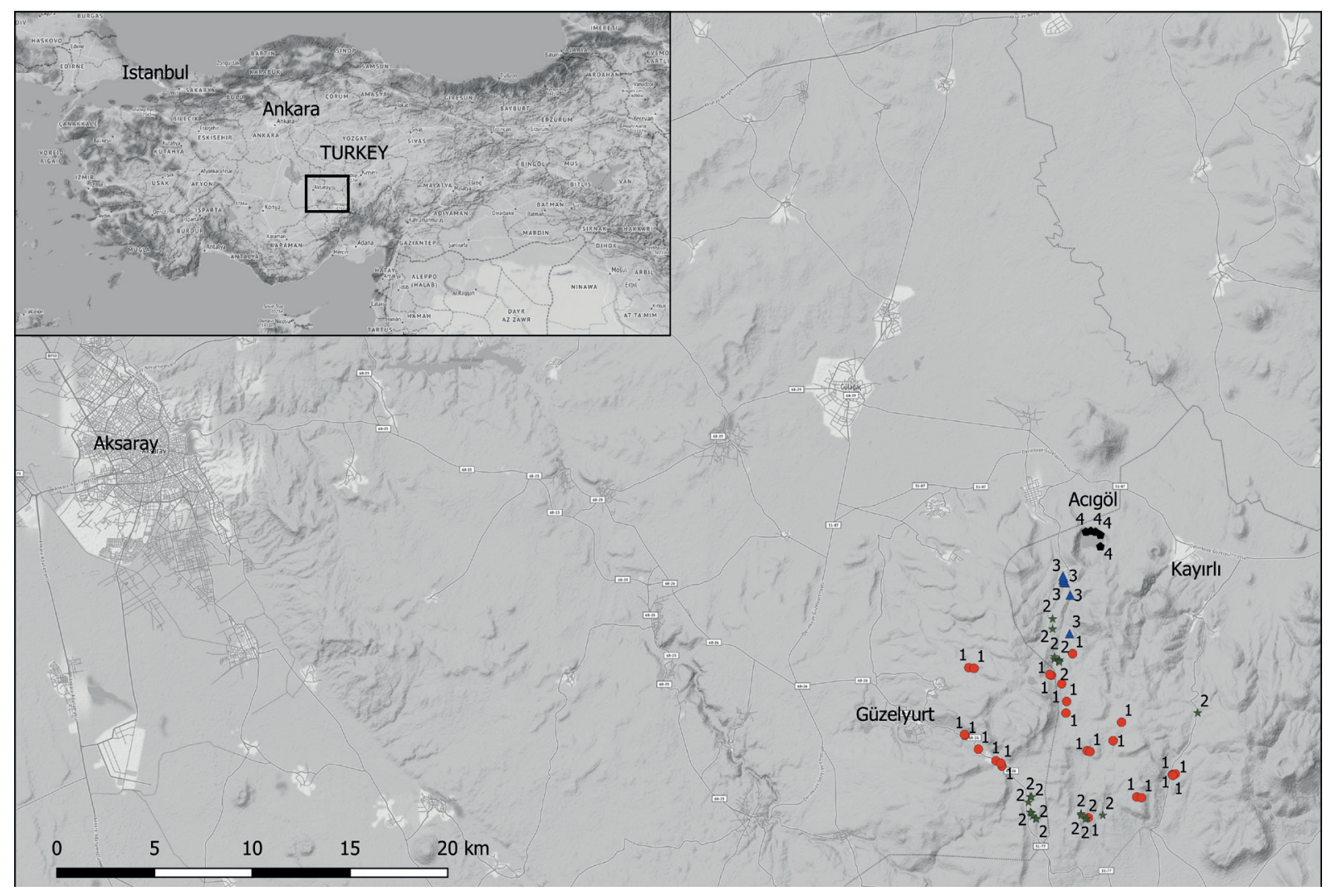

Figure 1: The study area with points of relevé locations (numbers indicate the communities; 1. Astragaletum plumoso-microcephalii; 2. Cotoneastro nummulariae-Quercetum pubescentis; 3. Pastinaco sativae-Populetum nigrae; 4. Phragmites australis).

Slika 1: Preučevano območje s točkami, ki predstavljajo lokacije popisov (številke predstavljajo združbe; 1 . Astragaletum plumoso-microcephalii; 2. Cotoneastro nummulariae-Quercetum pubescentis; 3. Pastinaco sativae-Populetum nigrae; 4. Phragmites australis). 
high rate as compared to the biological diversity in other countries of the temperate zone (Şekercioğlu et al. 2011). The high species richness results from its biological and evolutionary status that serve a passage of migration and a refugium of plants and animals in the past glacial periods (Bilgin 2011). In addition to being an important because of the high biodiversity, increasing anthropogenic pressures make Central Anatolian vegetation is a fairly sensitive ecosystem (Kaya \& Raynal 2001, Tavşanoğlu 2017). It was estimated that more than $44 \%$ of the natural steppe and forest-steppe area of Turkey have been mainly converted into croplands (Ambarlı et al. 2016). The Central Anatolian wetlands are also particularly have been most affected by the misapplication of water resource policies of Turkey. Thus, both terrestrial habitats and wetland ecosystems in the Central Anatolia have been under human disturbance and this is a serious threat for many species. For this reason, the phytosociological data on such highly diverse vegetation can serve a good basis for subsequent assessment and monitoring of biodiversity (Dengler et al. 2008). In this context, the syntaxonomical classification condensing compositional and structural information within a hierarchical system indicates historical, sociologi$\mathrm{cal}$, and habitat factors influencing the actual and potential vegetation (Blasi \& Burrascano 2013).

The steppe and forest-steppe vegetation have been phytosociologically well studied in Central Anatolia (Kurt et al. 2006, Ketenoğlu et al. 2010). First contribution on the studies of steppe vegetation in Central Anatolia were made by Zohary (1973), whose classification was more or less based on the dominance principle (Kürschner \& Parolly 2012). More detailed phytosociological studies on steppe and forest-steppe, following the Braun-Blanquet (1964) approach, were performed by Akman (1974, 1990), Akman et al. (1984, 1986, 1994, 1996), Aydoğdu et al. (1994, 1999, 2004), Yurdakulol et al. (1990), Ketenoğlu et al. (1996), Hamzaoğlu (2005), whereas a few phytosociological studies were conducted on wetland vegetation in Turkey (Akman et al. 1993, Seçmen \& Leblebici 1996, Seçmen \& Leblebici 1997, Kutbay et al. 1998, Karaömerlioğlu 2007, Kavgaci et al. 2011, Korkmaz et al. 2012, Özdeniz et al. 2016). However, there are still gaps concerning phytosociological data of steppe, foreststeppe, and wetland communities in Central Anatolia due to unsurveyed areas. According to Uğurlu et al. (2012), Quercus-dominated woodlands with junipers (J. excelsa M. Bieb., J. oxycedrus L.) in forest-steppe habitats of Central Anatolia were poorly studied. For this reason, we aimed to fill at least one of these gaps by contributing to the syntaxonomy, ecology, and diversity of the steppe, forest-steppe, and wetland communities in the southeastern part of Central Anatolia. Furthermore, we expect to have more exhaustive information about these communities in floristic and ecological aspect by means of this study that will provide an inventory of vegetation for the Natura 2000 ecological network.

\section{Methods}

\section{Study Area}

The study area located between Aksaray and Niğde provinces of Central Anatolia. The area is surrounded by Güzelyurt village (Aksaray) in the west, Narköy village (Niğde) in the north, Bozköy village (Niğde) in the south, and Kayırlı village (Niğde) in the east (Figure 1). The altitude of the study area varies between $1400 \mathrm{~m}$ and 1900 $\mathrm{m}$ a.s.l. The study area is situated in the Irano-Turanian phytogeographic region, which is the richest region in Anatolia in terms of plant diversity and endemic plants. It remains in B5 square according to Davis's grid system (Davis 1965-1985).

The area is composed of upper Miocene-Pliocene volcanic rocks and quaternary deposits. The bedrock of the area is andesite, basalt, tuff, rhyolite, and ignimbrite. The main soil types of the study area are brown non-calcareous soils and brown forest soils (Dizdar 2003). A lower semi-arid and extremely cold Mediterranean climate prevails in the region with, cold winters with frost periods, and hot and arid summers. The average annual precipitation of the region varies between $341.1 \mathrm{~mm}$ and $346 \mathrm{~mm}$, the average annual temperature is between $11.2^{\circ} \mathrm{C}$ and $12.1^{\circ} \mathrm{C}$, and mean of the maximum temperatures of the hottest month $30.6{ }^{\circ} \mathrm{C}$ and $29.5^{\circ} \mathrm{C}$ (Table 1 ).

Table 1: Bioclimatic synthesis.

Tabela 1: Bioklimatski dejavniki.

\begin{tabular}{|c|c|c|c|c|c|c|c|c|}
\hline Station & $\mathbf{P}(\mathrm{mm})$ & $\mathrm{M}\left({ }^{\circ} \mathrm{C}\right)$ & $\mathbf{m}\left({ }^{\circ} \mathrm{C}\right)$ & PE & Q & S & Prep. regime & Bioclimate type \\
\hline Niğgde & 341.1 & 29.5 & -4.6 & 34.9 & 35 & 1.2 & Sp. W. A. Su. & Lower semi-arid very cold Mediterranean climate \\
\hline Aksaray & 346 & 30.6 & -3.7 & 37.5 & 35.2 & 1.2 & Sp. W. A. Su. & Lower semi-arid very cold Mediterranean climate \\
\hline
\end{tabular}

P: Annual mean precipitation $(\mathrm{mm}) ; \mathrm{M}$ : Mean of the maximum temperatures of the hottest month $\left({ }^{\circ} \mathrm{C}\right)$; m: Mean of the minimum temperatures of the coldest month $\left({ }^{\circ} \mathrm{C}\right)$; PE: Summer precipitation $(\mathrm{mm})$; $\mathrm{S}$ : Drough index $\mathrm{S}=\mathrm{PE} / \mathrm{M}$; Q: Emberger rainfall index $\mathrm{Q}=2000 \times \mathrm{P} /(\mathrm{M}+\mathrm{m}+546.6)(\mathrm{M}-\mathrm{m})$ 


\section{Data collection}

Steppe, forest-steppe, riparian, and shoreline communities were studied using the Braun-Blanquet method (Braun-Blanquet 1964) and all relevés were sampled from floristically and physiognomically homogenous habitats (Braun-Blanquet 1964) during vegetation period of the summer of 2016. The Minimal Area Method (Braun-Blanquet 1964) was used to determine relevé sizes; as 64 $\mathrm{m}^{2}$ for steppe vegetation, $284 \mathrm{~m}^{2}$ for forest-steppe vegetation, and $25 \mathrm{~m}^{2}$ for riparian and wetland vegetation. A complete list of vascular plants and their cover-abundance values on a seven-degree scale were recorded $(r,+, 1,2,3$, 4 and 5). "Flora of Turkey and the Aegean Islands" and "The Checklist of the Flora of Turkey-Vascular Plants" were referred to identify the specimens recording (Davis 1965-1985, Güner et al. 2012). All specimens were preserved at the Herbarium of Ankara University (ANK) and Aksaray University (AKSU). Climatic data were obtained from the website of General Directorate of Meteorological Service (MGM 2017) and bioclimatic synthesis of the study area was determined by Akman \& Daget (1971). Soil samples were taken from various sample plots representing the different plant formations and from depths ranging between 0 and $30 \mathrm{~cm}$. The measurements of particle size (Richards 1954), organic matter (Walkley \& Black 1934), nitrogen (Kjeldahl 1883), potassium (Ammonium acetate), phosphorous spectrophotometrically (Olsen 1954), lime-Scheibler method (Jackson 1958), salt, $\mathrm{pH}$ (pH meter), EC (EC meter) were performed.

\section{Data Analysis}

Vegetation data and 69 sample plots in total were stored in TURBOVEG database (Hennekens \& Schaminée 2001) and transferred to JUICE (Tichý 2002). The relevés were classified utilizing the TWINSPAN (Cut levels 0, 2, 5 , and 25) (Hill 1979).

The potential annual radiation index (PDIR) and heatload were calculated using the latitude, slope inclination, and aspect of the relevés using equation proposed by McCune (2007). The Ellenberg Indicator Values (EIVs) of the species were generated by Ellenberg Indicator Values, which were prepared for the Flora Europea by Pignatti (2005). EIVs were arranged for light, temperature, moisture, continentality, soil reaction, and nutrients. EIVs were assigned to the species data and average values were calculated for each relevé in the JUICE. On average, EIVs could be assigned to $50 \%$ of the species of a relevé (minimum $18 \%$, maximum $86 \%$ ).

The species diversity of each relevé was determined according to the Shannon-Wiener index. Unconstrained ordination was used to find major gradients in species composition and describe the general pattern in species distribution along the gradients. The dataset was subjected to detrended correspondence analysis (DCA) using CANOCO 4.5 (Ter Braak \& Smilauer 2002). The Monte Carlo permutation test 499 numbers of permutations under full model) was further applied in order to determine the statistical significance of measured environmental variables (altitude, inclination, PDIR and heat-load index) in explaining the species composition using "stepwise forward selection" of explanatory variables under CANOCO 4.5.

The species richness in five associations and sub-associtions was estimated using sample-based rarefaction that allows suitable comparison of species richness estimated from samples in different sizes (Koellner et al. 2004, Chiarucci et al. 2009, Gotelli \& Colwell 2011). The rarefaction curves were created using the 'vegan' package in the R program (Oksanen et al., 2015, R Development Core Team 2015). In order to evaluate the degree of floristic resemblance between the new associations in the study area and the plant associations previously identified by other researchers were compared using the Sørensen's Similarity Index (Sørensen 1948). It was calculated as $[2 \mathrm{C} /(\mathrm{A}+\mathrm{B})] \times 100$, where $(\mathrm{A})$ and $(\mathrm{B})$ are the total species in the previously described association (A) and in the newly described association (B) respectively, while $(C)$ is the number of species common to both associations. The threshold value is accepted as above $50 \%$ for floristic similarity. Characteristic species of higher units were taken from Akman et al. (1978a, b, c) and Quézel et al. (1978). The rules of the International Code of Phytosociological Nomenclature (Weber et al. 2000) were followed in naming the new syntaxa.

\section{Results}

The TWINSPAN classification revealed a drought gradient from left to right in the vegetation table (Table 3-6). On the first and second level of division, shoreline (6 relevés), and riparian vegetation (8 relevés), were clearly separated from forest-steppe vegetation. On the third level, forest-steppe vegetation (27 relevés) was separated from the steppe vegetation (28 relevés), except 3 relevés of forest-steppe vegetation, which were situated within steppe vegetation due to high similarity $(56.4 \%$ similarity). Especially, Quercus pubescens-dominated forest had many common species with steppe vegetation due to its low tree cover (Figure 4 and 6). These relevés were included in forest-steppe vegetation. Only forest-steppe vegetation was divided into two sub-associations with 
a separate classification, whereas other vegetation types were not further divided since they had a homogenous floristic composition.

\section{Description of vegetation units}

Unit 1: Phragmites australis (Cav.) Trin. ex Steudel community in Table 3.

This community is dominated by Phragmites australis (Cav.) Trin. ex Steudel which generally occurs along shoreline, riparian areas, coasts, and marshes. In the study area, the community distribute along the shoreline of Narligöl in the north of study area between 1360 and $1372 \mathrm{~m}$ a.s.l. (Figure 2). Polypogon monspeliensis (L.) Desf., Conyza canadensis (L.) Cronquist, and Carthamus glaucus M. Bieb. subsp. glaucus are the other coexisting species in the Phragmites community. The community occurs on sandy clay loam, non-salty $(0.0055 \%)$, neutral (pH: 7.34), and medium calcareous soils (14.86\%; in

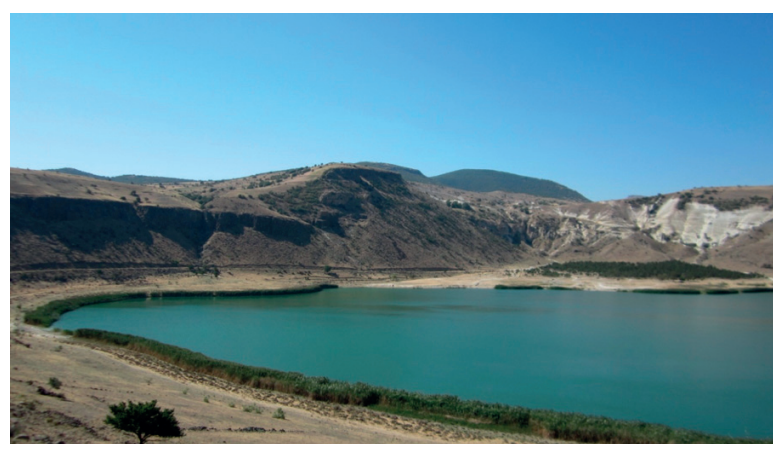

Figure 2: Phragmites australis community in Narlıöl. Photo: Fatoş Şekerciler.

Slika 2: Združba z vrsto Phragmites australis pri jezeru Narlıgöl. Foto: Fatoş Şekerciler.

Table 2). The organic matter (1.93\%) and phosphorous (11.43 ppm) content of the soils are low, whereas nitrogen amount $(0.1105 \%)$ is adequate.

Table 2: The soil characteristics of the vegetation types in the study area.

Tabela 2: Značilnosti tal vegetacijskih tipov na preučevanem območju.

\begin{tabular}{|c|c|c|c|c|c|c|c|c|c|c|c|}
\hline Vegetation type & $\begin{array}{l}\text { Sand } \\
(\%)\end{array}$ & $\begin{array}{l}\text { Silt } \\
(\%)\end{array}$ & $\begin{array}{l}\text { Clay } \\
(\%)\end{array}$ & $\begin{array}{c}\mathrm{NaCl} \\
(\%)\end{array}$ & $\begin{array}{c}\mathrm{EC} \\
(\mathrm{dS} / \mathrm{m})\end{array}$ & pH & $\begin{array}{c}\text { Org. } \\
\text { Matter (\%) }\end{array}$ & $\begin{array}{c}\mathbf{P} \\
(\mathrm{ppm})\end{array}$ & $\begin{array}{c}\mathrm{K} \\
(\mathrm{ppm})\end{array}$ & $\begin{array}{c}\mathrm{CaCO} 3 \\
(\%)\end{array}$ & $\begin{array}{l}\mathbf{N} \\
(\%)\end{array}$ \\
\hline \multirow[t]{5}{*}{ Steppe vegetation } & 52.6 & 9.9 & 37.6 & 0.0 & 0.4 & 6.7 & 1.0 & 5.1 & 173.6 & 1.5 & 0.1 \\
\hline & 64.6 & 25.9 & 9.6 & 0.0 & 0.1 & 7.8 & 0.5 & 7.0 & 99.9 & 1.8 & 0.1 \\
\hline & 54.6 & 21.9 & 23.6 & 0.0 & 0.2 & 6.9 & 1.7 & 6.0 & 100.0 & 1.5 & 0.1 \\
\hline & 72.6 & 15.9 & 11.6 & 0.0 & 0.1 & 7.1 & 0.3 & 4.0 & 55.0 & 0.9 & 0.1 \\
\hline & 54.6 & 17.9 & 27.6 & 0.0 & 0.2 & 6.9 & 1.6 & 7.0 & 113.7 & 1.9 & 0.1 \\
\hline Forest-steppe (typicum) & 54.6 & 17.9 & 27.6 & 0.0 & 0.2 & 5.3 & 0.5 & 52.6 & 81.9 & 1.5 & 0.0 \\
\hline \multirow[t]{3}{*}{ Forest-steppe (quercetosum trojanae) } & 40.6 & 5.9 & 53.6 & 0.0 & 0.5 & 7.0 & 1.9 & 6.4 & 211.2 & 7.3 & 0.1 \\
\hline & 30.6 & 19.9 & 49.6 & 0.0 & 0.3 & 6.8 & 2.6 & 9.5 & 212.5 & 2.5 & 0.1 \\
\hline & 32.6 & 15.9 & 51.6 & 0.0 & 0.5 & 7.0 & 1.9 & 7.9 & 191.1 & 0.9 & 0.1 \\
\hline Riparian vegetation & 58.6 & 17.9 & 23.6 & 0.0 & 0.3 & 7.3 & 3.0 & 19.8 & 359.5 & 2.6 & 0.0 \\
\hline Lakeside vegetation & 62.6 & 9.9 & 27.6 & 0.0 & 0.2 & 7.3 & 1.9 & 11.4 & 69.7 & 14.9 & 0.1 \\
\hline
\end{tabular}

Table 3: Phragmites australis community.

Tabela 3: Združba z vrsto Phragmites australis.

\begin{tabular}{|c|c|c|c|c|c|c|}
\hline & 61 & 62 & 63 & 64 & 65 & 66 \\
\hline Twinspan division 1 & 1 & 1 & 1 & 1 & 1 & 1 \\
\hline Altitude (m) & 1357 & 1369 & 1368 & 1368 & 1371 & 1372 \\
\hline Aspect & W & W & SW & $S$ & SE & SE \\
\hline Inclination $\left(^{\circ}\right)$ & 5 & 5 & 5 & 5 & 5 & 5 \\
\hline Relevé size ( $\left.\mathbf{m}^{2}\right)$ & 25 & 25 & 25 & 25 & 25 & 25 \\
\hline Vegetation cover (\%) & 70 & 70 & 65 & 70 & 65 & 70 \\
\hline Phragmites australis & 3 & 3 & 3 & 3 & 3 & 3 \\
\hline Polypogon monspeliensis & 1 & + & + & 1 & + & + \\
\hline Conyza canadensis & + & 1 & + & + & + & + \\
\hline Carthamus glaucus & 1 & + & + & + & + & . \\
\hline \multicolumn{7}{|c|}{ Characteristic species of Phragmition communis } \\
\hline Schoenoplectus lacustris subsp. lacustris & 2 & 1 & + & 1 & . & . \\
\hline
\end{tabular}




\begin{tabular}{|c|c|c|c|c|c|c|}
\hline & 61 & 62 & 63 & 64 & 65 & 66 \\
\hline \multicolumn{7}{|c|}{ Characteristic species of Phragmito-Magnocaricetea and Phragmitetalia } \\
\hline Mentha longifolia subsp. thyphoides & 1 & + & + & + & . & + \\
\hline Epilobium hirsutum & 1 & 1 & + & 1 & . & . \\
\hline Companions & . & . & . & . & . & . \\
\hline Bromus tectorum & + & + & + & + & + & + \\
\hline Solanum luteum & 2 & 2 & 1 & 2 & . & . \\
\hline Polypogon viridis & 1 & + & 1 & . & . & + \\
\hline Centaurea solstitialis & 1 & + & 1 & 1 & . & . \\
\hline Achillea cappadocica & + & + & + & + & . & . \\
\hline Echinops ritro & . & . & 1 & 1 & 1 & 1 \\
\hline Juncus heldreichianus subsp. orientalis & 1 & + & . & . & . & 2 \\
\hline Asperula stricta subsp. stricta & . & 1 & . & . & 1 & 1 \\
\hline Reseda lutea & + & . & . & . & + & + \\
\hline Cynodon dactylon & . & + & . & . & + & + \\
\hline Convolvulus arvensis & . & + & . & . & + & + \\
\hline Juncus heldreichianus subsp. orientalis & 1 & + & . & . & . & 2 \\
\hline
\end{tabular}

Unit 2: Pastinaco sativae-Populetum nigrae ass. nov. hoc loco Holotypus Relevé 52 in Table 4.

Characteristic species: Populus nigra L. subsp. nigra, Pastinaca sativa L. subsp. urens, Elaeagnus angustifolia L., Mentha longifolia (L.) Hudson subsp. thyphoides (Briq.) Harley, Cirsium pubigerum (Desf.) DC., Juncus inflexus L. subsp. inflexus, Catabrosa aquatica (L.) P. (Beauv.).

The association is dominated by Populus nigra $\mathrm{L}$. which forms mixtures with Populus alba L., Salix spp. L., Acer spp. L., Carpinus spp. L., Ulmus spp. L., Fraxinus spp. L. in mixed riparian forests and with oaks in old forests. This association is found in riparian areas within Narköy village (Figure 3 ). The inclination varies between $30^{\circ}$ and $45^{\circ}$, and the altitude ranges from $1388 \mathrm{~m}$ to $1447 \mathrm{~m}$ a.s.l.

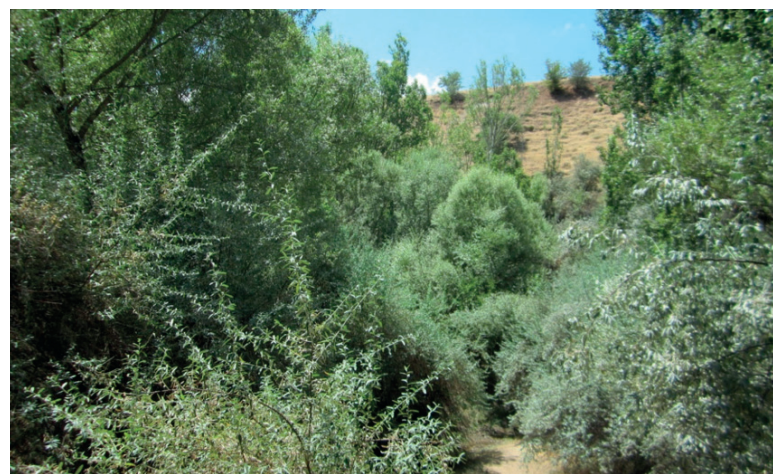

Figure 3: Pastinaco sativae-Populetum nigrae association in Narköy village. Photo: Fatoş Şekerciler.

Slika 3: Asociacija Pastinaco sativae-Populetum nigrae pri jezeru v vasi Narköy. Foto: Fatoș Șekerciler.

Table 4 (Tabela 4): Pastinaco sativae-Populetum albae.

\begin{tabular}{|c|c|c|c|c|c|c|c|c|}
\hline Relevé No & 49 & 50 & 51 & $52^{*}$ & 53 & 54 & 55 & 56 \\
\hline Twinspan division 1 & 0 & 0 & 0 & 0 & 0 & 0 & 0 & 0 \\
\hline Twinspan division 2 & 1 & 1 & 1 & 1 & 1 & 1 & 1 & 1 \\
\hline Altitude (m) & 1388 & 1444 & 1447 & 1428 & 1429 & 1424 & 1419 & 1416 \\
\hline Aspect & SW & W & $\mathrm{NE}$ & SW & SW & SSW & $\mathrm{NE}$ & SEE \\
\hline Inclination $\left(^{\circ}\right)$ & 45 & 45 & 30 & 40 & 40 & 40 & 40 & 30 \\
\hline Relevé size $\left(\mathbf{m}^{2}\right)$ & 25 & 25 & 25 & 25 & 25 & 25 & 25 & 25 \\
\hline Vegetation cover $(\%)$ & 70 & 80 & 65 & 80 & 80 & 80 & 85 & 85 \\
\hline \multicolumn{9}{|c|}{ Characteristic species of the association } \\
\hline Populus nigra subsp. nigra & 3 & 4 & 3 & 2 & 3 & 3 & 3 & 3 \\
\hline Pastinaca sativa & 2 & . & . & 1 & 1 & 1 & 2 & 2 \\
\hline Elaeagnus angustifolia & 1 & 3 & 2 & 2 & 1 & . & . & . \\
\hline Mentha longifolia subsp. thyphoides & . & 2 & . & 1 & 1 & . & 2 & 2 \\
\hline Cirsium pubigerum & . & . & . & 1 & . & 1 & 1 & . \\
\hline Juncus inflexus & 1 & 2 & 1 & . & . & . & . & . \\
\hline Catabrosa aquatica & 2 & . & . & . & . & . & . & 2 \\
\hline
\end{tabular}


Characteristic species of Alno glutinosae-Populetea albae, Populetalia albae, Populion albae

Salix alba

Urtica dioica

Vitis sylvestris

Calamagrostis pseudophragmites

Characteristic species of Quercetea pubescentis

Crataegus monogyna var. monogyna

Characteristic species of Molinio-Arrhenathereta and Arrhenatheretalia

Alopecurus arundinaceus

Dactylis glomerata

Epilobium hirsutum

Plantago major

Lotus corniculatus

Companions

Rosa canina

Agrostis capillaris

Elymus hispidus subsp. hispidus

Sonchus asper subsp. glaucens

Medicago sativa subsp. sativa

Lolium rigidum var. rigidum

Pyrus communis subsp. sativa

Carthamus glaucus

Trifolium elongatum

Sanguisorba minor subsp. balearica

Cydonia oblonga

Ononis spinosa subsp. leiosperma

Ephedra major

Festuca valesiaca

Cota tinctoria

Eryngium campestre

Vicia cracca subsp. cracca

Colutea cilicica

Allium paniculatum subsp. paniculatum

Trifolium physodes subsp. physodes

Cotoneaster nummularius

Cirsium lappaceum subsp. anatolicum

Carex hirta

Tanacetum parthenium

Cerasus mahaleb

Berberis vulgaris

Viscum album

The association occurs on the south-western and northeastern slopes. The vegetation cover varies between $65 \%$ and $85 \%$. Soil of the association is rich in terms of phosphorus (19.80 ppm) and potassium content (359.51 ppm; in Table 2). However, it is mediocre and poor in terms of organic matter (3.04\%) and nitrogen amount (0.0421\%), respectively. The soils are also neutral $(\mathrm{pH}: 7.32)$.
Unit 3: Cotoneastro nummulariae-Quercetum pubescentis ass. nov. hoc loco

Holotypus, Relevé 58 in Table 5.

Characteristic species: Quercus pubescens Willd., Phleum montanum C. Kroch, Juniperus oxycedrus L. subsp. oxycedrus, Cotoneaster nummularia Fisch. and Mey

The dominant species of the association is Quercus pubescens which has a wide distribution ranging from the 


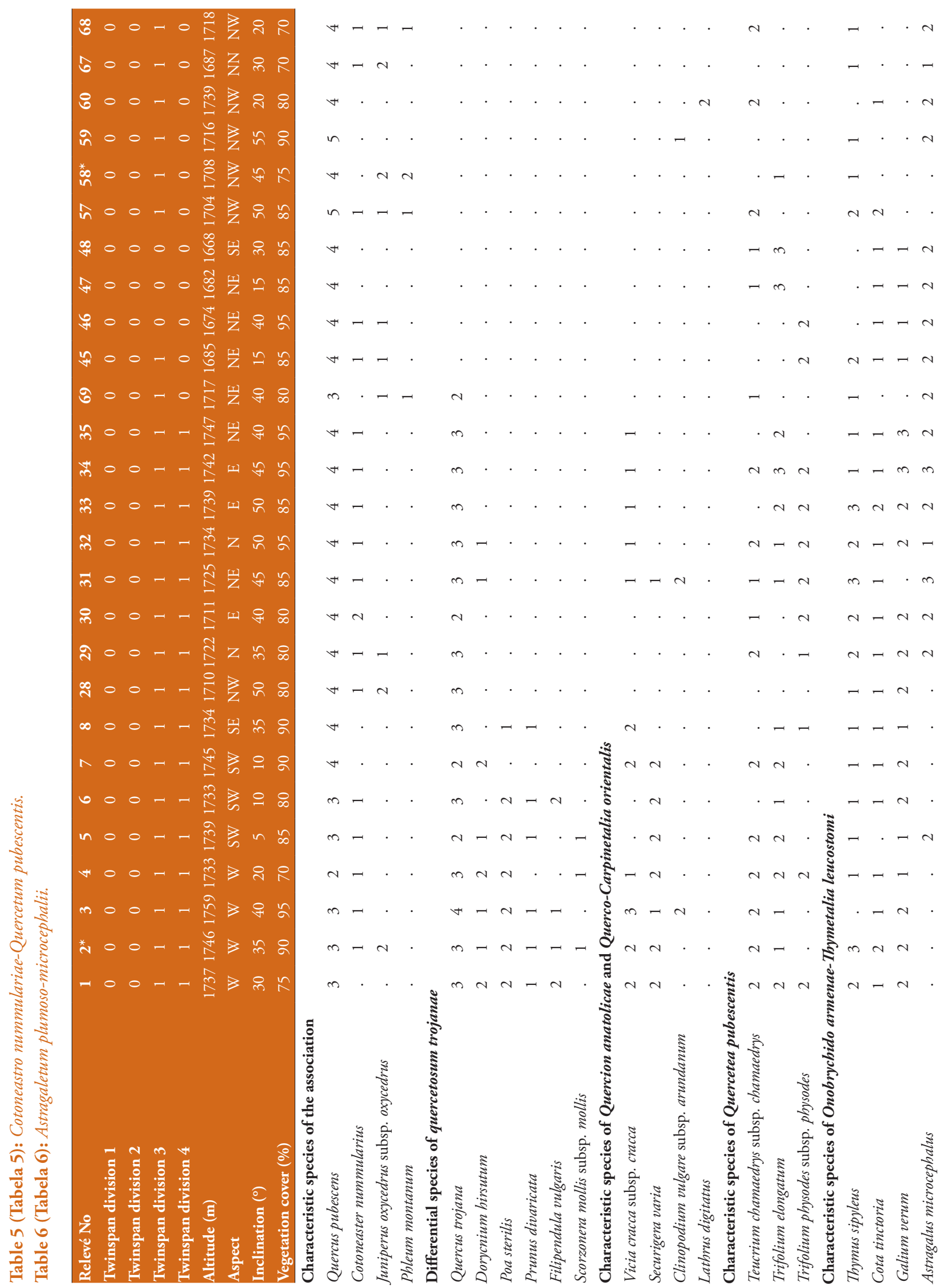




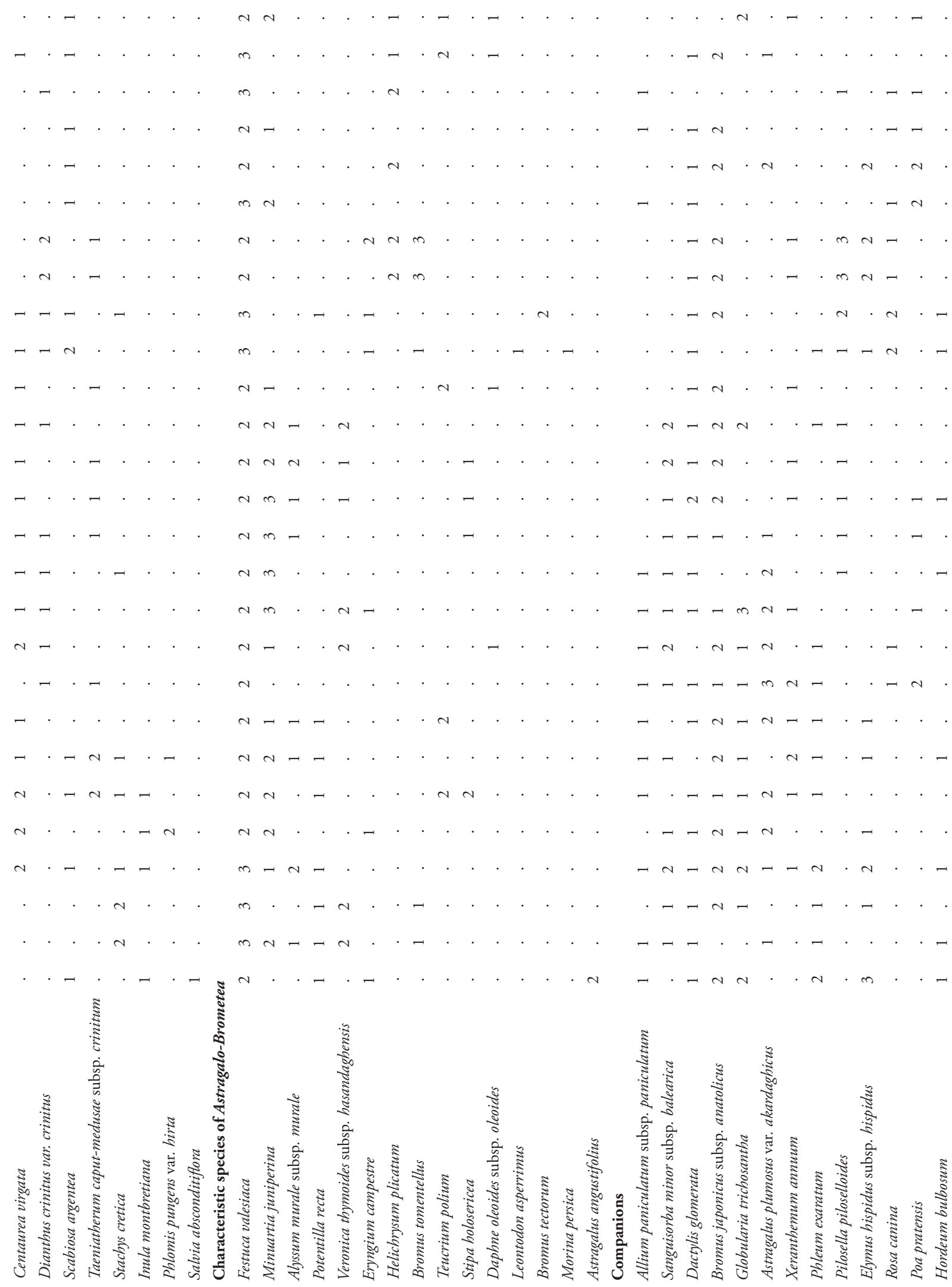




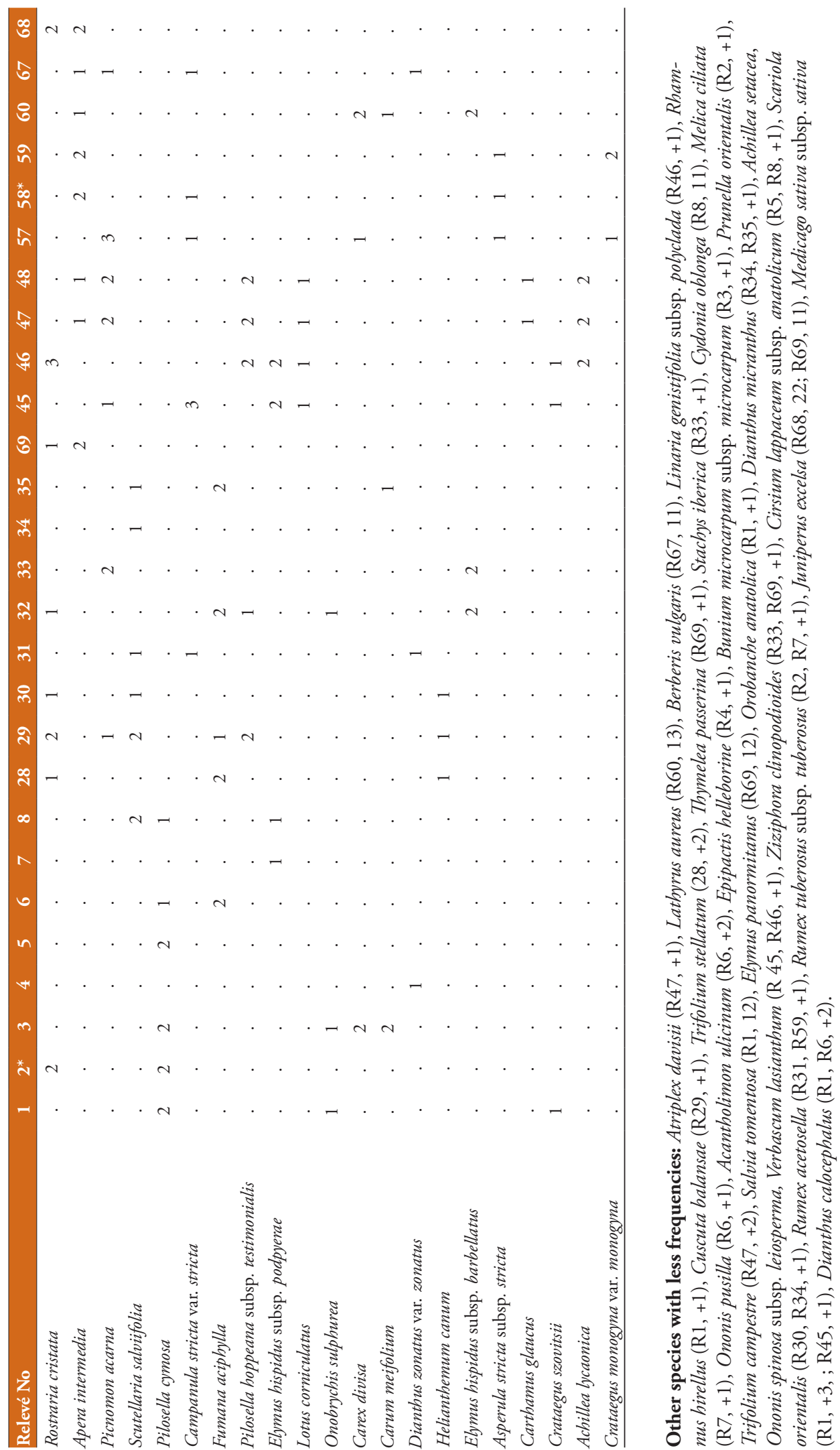


West, Central, and South Europe to Crimea and Anatolia due to drought tolerance (Davis 1965-1985). It could cope with both moderate summer drought stress and low winter temperatures (Pasta et al. 2016). Q. pubescens coexists with Phleum montanum, Juniperus oxycedrus subsp. oxycedrus, and Cotoneaster nummularia in the study area. They are native species in the woodlands and grasslands of the Mediterranean and Irano-Turanian regions and their altitudinal range varies from sea level to $2200 \mathrm{~m}$ a.s.l. (Davis 1965-1985). The vegetation cover is high and varyies from $70 \%$ to $95 \%$. The altitudinal range of the association is between $1400 \mathrm{~m}$ and $1750 \mathrm{~m}$ a.s.l., and the inclination varies between $5^{\circ}$ and $55^{\circ}$. The association usually distributes in north-eastern, north-western, western, and south-western slopes between Bozköy and Kayırlı villages, around Narköy village and the upland of Divarlı (Figure 4).

Two sub-associations of Cotoneastro nummulariaeQuercetum pubescentis are described in the study area.

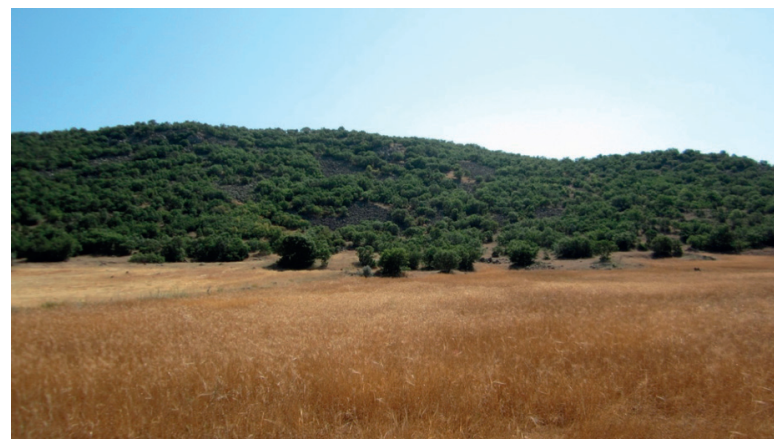

Figure 4: Cotoneastro nummulariae-Quercetum pubescentis between Güzelyurt and Bozköy. Photo: Nihal Kenar.

Slika 4: Cotoneastro nummulariae-Quercetum pubescentis med mestoma Güzelyurt in Bozköy. Foto: Nihal Kenar.

Unit 3.1: quercetosum trojanae subass. nov. hoc loco Holotypus Relevé 2 in Table 5.

Differential species: Quercus trojana P.B. Webb subsp. trojana, Dorycnium hirsutum (L.) Ser., Poa sterilis Bieb., Prunus divaricata Ledeb., Filipendula vulgaris Moench, Scorzonera mollis Bieb. subsp. mollis.

Quercus trojana subsp. trojana, an East Mediterranean element, coexists with other deciduous Quercus species and Pinus brutia Ten. in the northwest, west, and southwest of Anatolia between $300 \mathrm{~m}$ and $1800 \mathrm{~m}$ a.s.l. Differential species of quercetosum trojanae are Dorycnium hirsutum, Poa sterilis, Prunus divaricata, Filipendula vulgaris, Scorzonera mollis subsp. mollis. The sub-association is found in Divarlı upland and western, south-western, and north-western slopes where the inclination varies between $5^{\circ}$ and $50^{\circ}$. The altitudinal range is between 1700 $\mathrm{m}$ and $1760 \mathrm{~m}$ a.s.l. The vegetation cover ranged between $70 \%$ and $95 \%$.
Unit 3.2: typicum subass. nov. hoc loco

Holotypus is the same as for the name of the association, Relevé 58 in Table 5.

Differential species: Phleum montanum C. Kroch, Juniperus oxycedrus L. subsp. oxycedrus

The vegetation cover of the sub-association varies between $70 \%$ and $95 \%$. It occurs on slopes whose inclination is between $15^{\circ}$ and $55^{\circ}$. It is mostly found on the north-eastern and north-western slopes of Narköy upland and between Bozköy and Kayırlı villages at an altitude of about $1410 \mathrm{~m}$ and $1720 \mathrm{~m}$ a.s.l.

Unit 4: Astragaletum plumoso-microcephalii ass. nov. hoc loco Holotypus Relevé 38 in Table 6.

Characteristic species: Astragalus microcephalus Willd. subsp. microcephalus, Astragalus plumosus Willd., Allium paniculatum L. subsp. paniculatum

The dominant species of the association was Astragalus microcephalus subsp. microcephalus, which is widespread and a Irano-Turanian chamaephyte. A. microcephalus could occur up to $2700 \mathrm{~m}$, whilst $A$. plumosus and $A l$ lium paniculatum subsp. paniculatum is found only up to $2000 \mathrm{~m}$. The association distributes in Güzelyurt-Sivrihisar, Bozköy-Kayırlı, and Akyamaç villages, Kızılkilise, and Divarlı upland. It occurs on northern, north-western, and north-eastern slopes between $1650 \mathrm{~m}$ and 1800 $\mathrm{m}$ a.s.l. (Figure 5). The mean cover of the association varies between $75 \%$ and $95 \%$ between the inclinations from $5^{\circ}$ to $60^{\circ}$. The soils are non-saline $(0.0037 \%-0.0123 \%)$ and calcareous $(0.87 \%-1.75 \%$; in Table 2$)$. The soil texture was described as sandy clay and sandy loam. The amount of organic matter is low and between $0.31 \%$ and $1.65 \%$ in the soil. The amount of nitrogen, phosphorous, and potassium is between $0.0526 \%$ and $0.01158 \%, 3.96$ and $7.04 \mathrm{ppm}$, and 54.98 and $113.71 \mathrm{ppm}$ in the soil, respectively.

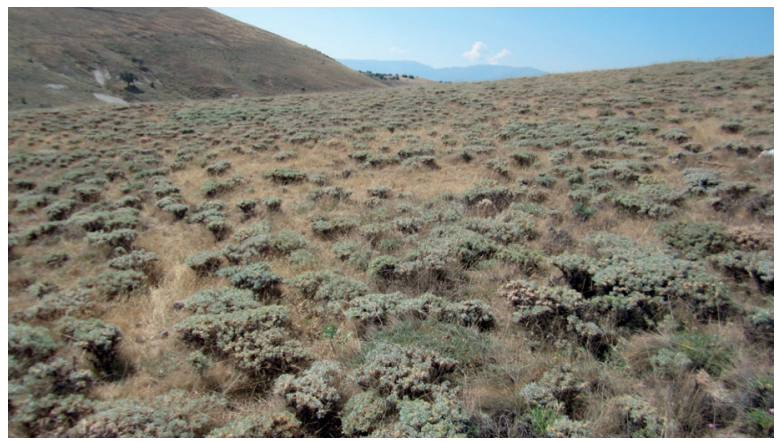

Figure 5: Astragaletum plumoso-microcephalii in upland of Divarlı village. Photo: Nihal Kenar.

Slika 5: Astragaletum plumoso-microcephalii na gorovju pri vasi Divarlı. Foto: Nihal Kenar. 


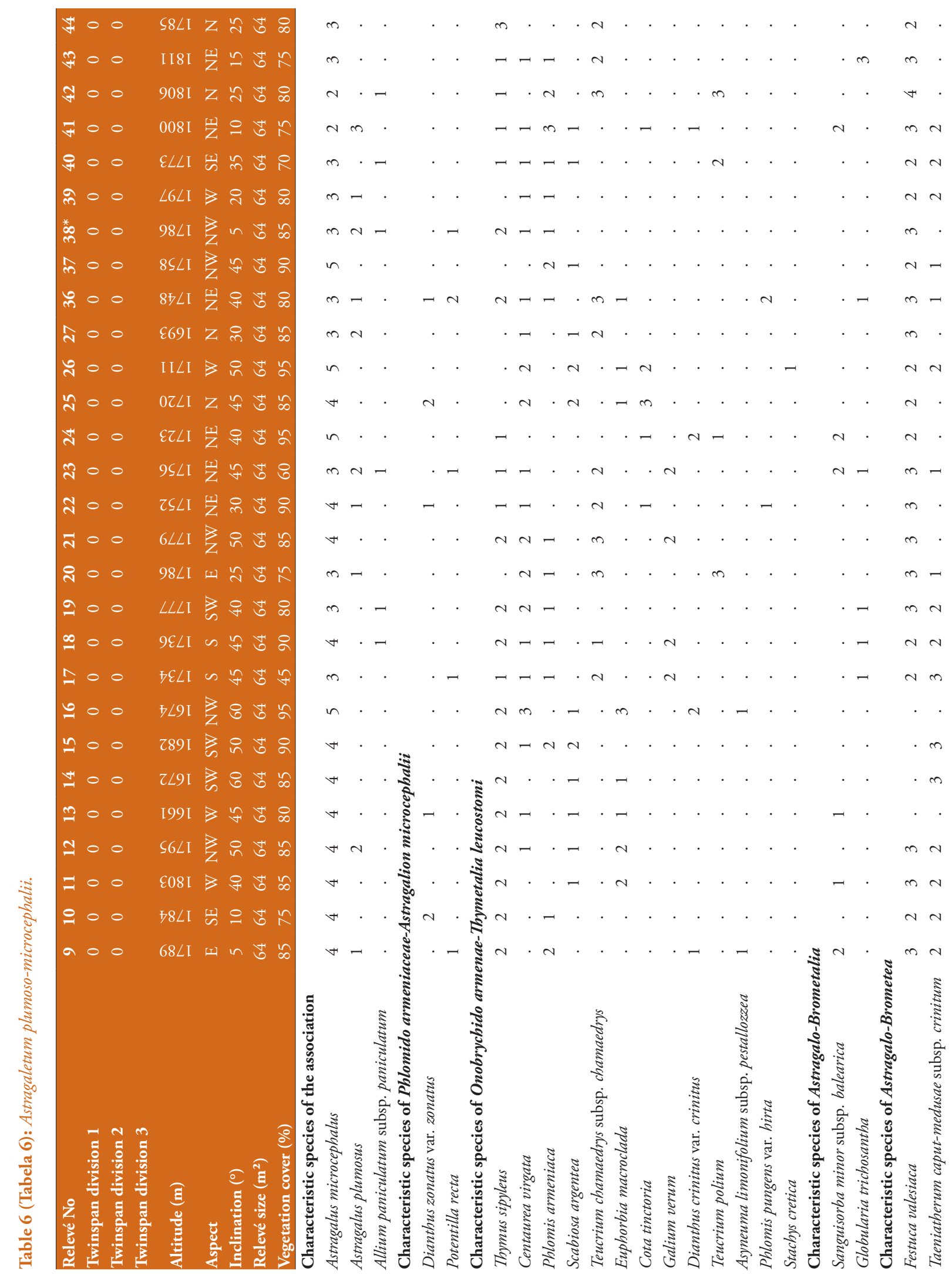




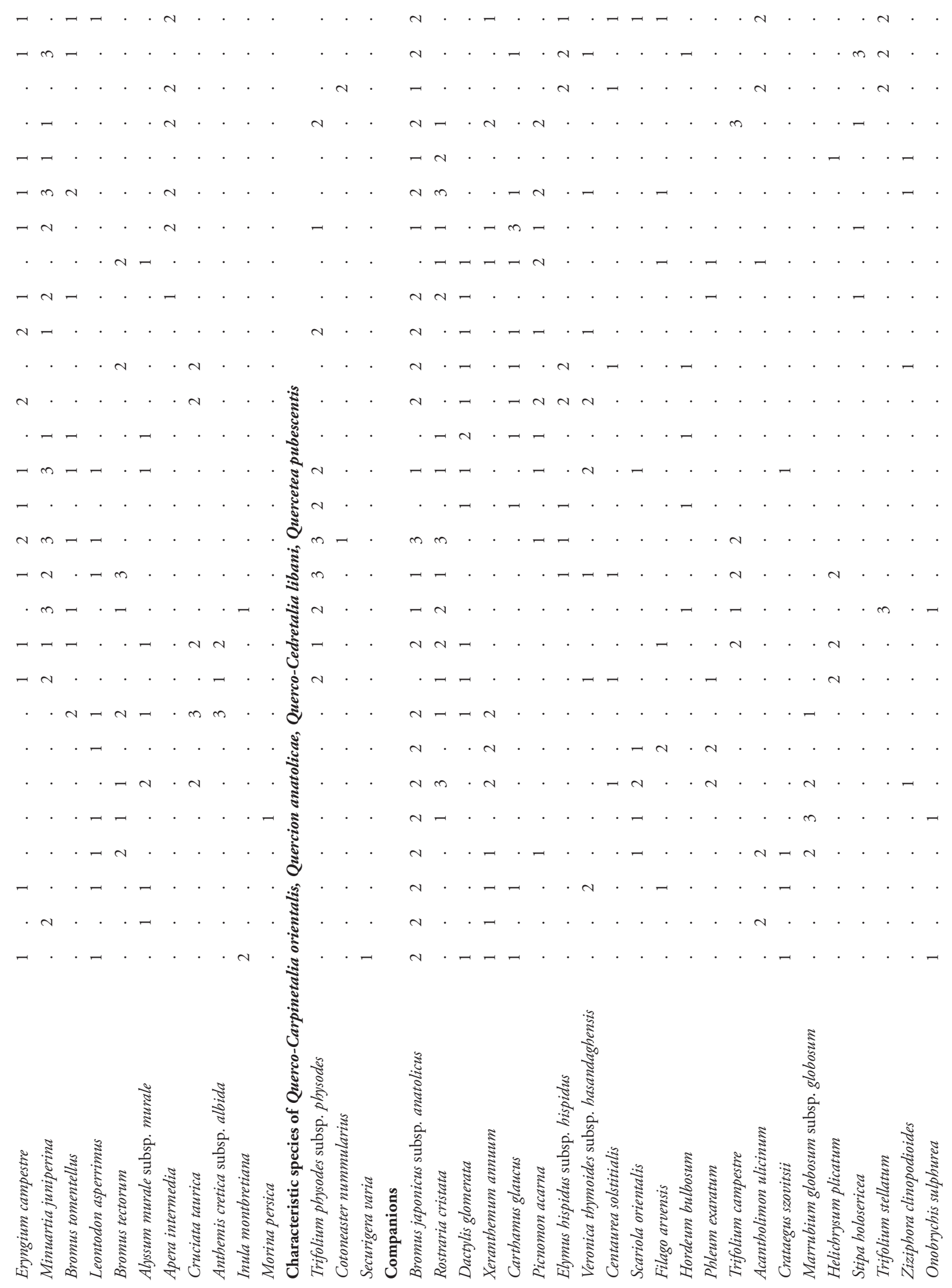




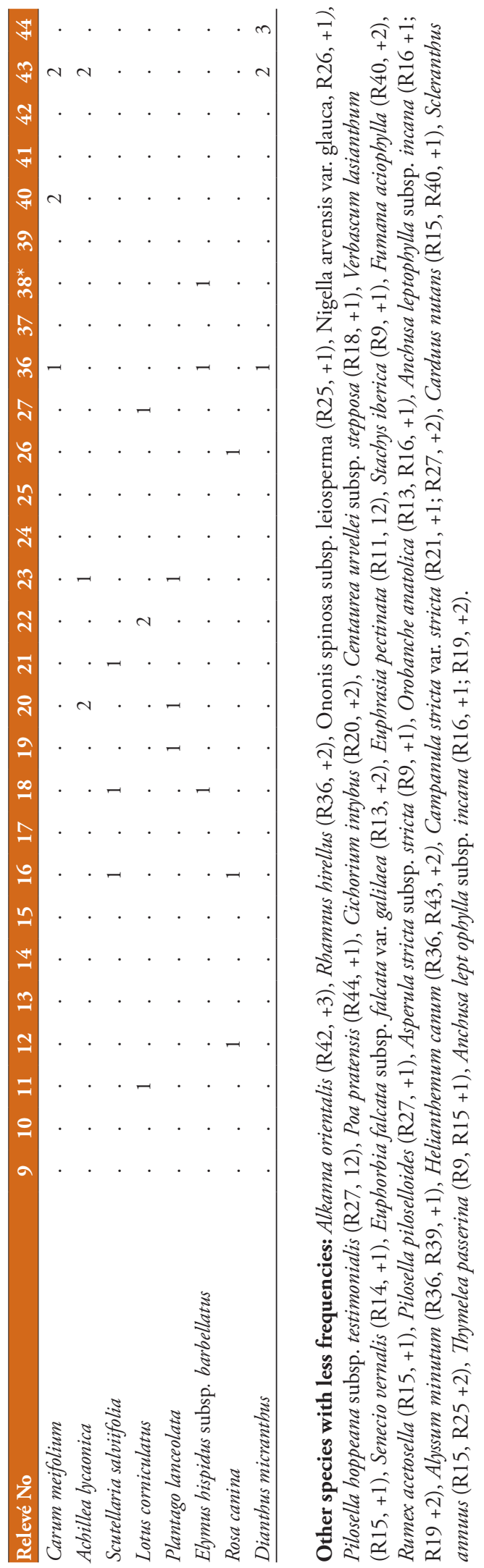

\section{Ordination analysis}

Classification groups were well separated in the ordination diagram (DCA) except subassociations of Cotoneastro nummulariae-Quercetum pubescentis due to high floristical similarities. However, these sub-associations differ in terms of both dominant species and differential species. Azonal communities (Phragmites australis community and Pastinaco sativae-Populetum nigrae), which occurred on the lowest parts of the study area, were associated with moisture and nutrient indicator values (Figure 6). Forest (Cotoneastro nummulariae-Quercetum pubescentis typicum subass. and Cotoneastero nummulariae-Quercetum pubescentis-quercetosum trojanae subass.) and steppe communities (Astragaletum plumoso-microcephalii), which occurred on the highest altitudes, were associated with continentality indicator values. Higher temperature indicator value and endemism ratio were observed in the forest community (Cotoneastero nummulariae-Quercetum pubescentis), whereas light indicator value was higher in the steppe community (Astragaletum plumoso-microcephalii). Among measured environmental variables, altitude $(\mathrm{F}=13.08, \mathrm{P}=0.002)$ and inclination $(\mathrm{F}=2.77, \mathrm{P}=0.04)$ had a significant effect on the variation of species composition, while radiation $(\mathrm{F}=1.95$, $\mathrm{P}=0.13)$ and heat-load $(\mathrm{F}=0.51, \mathrm{P}=0.7)$ indices had non-significant effects.

Main vegetation types of the study area (steppe, forest-steppe, riparian, and shoreline) showed variations according to altitude and inclination (Figure 7). While Phragmites australis community had the lowest species diversity, Cotoneastero nummulariae- Cotoneastro nummulariae-Quercetum pubescentis typicum and Quercetum pubescentis-quersetosum trojanae had the highest species diversity in the study area (Figure 8). This was followed by Astragaletum plumoso-microcephalii occuring on slopes with the high inclination (Figure 7). A total of 12 endemic taxa were determined in the study area of which 11 were classified as LC (least concern) and one as NT (Near threatened) according to IUCN red list categories (Ekim et al. 2000). The endemism rate of the study area was $7.83 \%$. The majority of the endemics were from Irano-Turanian region (5.42\%). The highest number of endemic species was found in Astragaletum plumoso-microcephalii followed by Cotoneastero nummulariae-Quercetum pubescentis quercetosum trojanae. Linaria genistifolia subsp. polyclada (NT category), was represented in one relevé of Cotoneastero nummulariaeQuercetum pubescentis. 

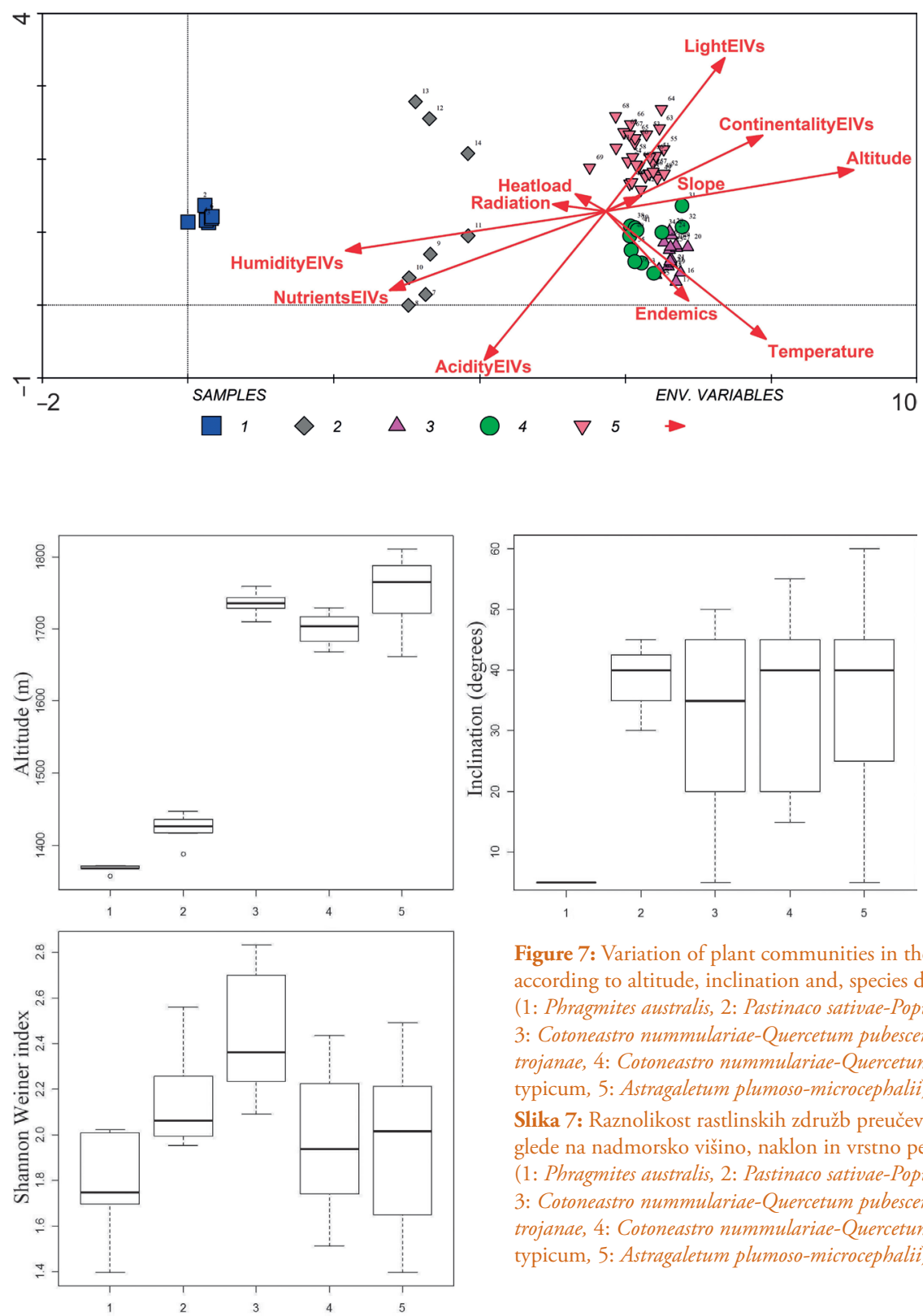

Figure 7: Variation of plant communities in the study area according to altitude, inclination and, species diversity (1: Phragmites australis, 2: Pastinaco sativae-Populetum nigrae, trojanae, 4: Cotoneastro nummulariae-Quercetum pubescentis typicum, 5: Astragaletum plumoso-microcephalii). glede na nadmorsko višino, naklon in vrstno pestrost typicum, 5: Astragaletum plumoso-microcephalii).
Figure 6: DCA analysis of plant communities in the study area (1. Phragmites australis, 2. Pastinaco sativae-Populetum nigrae, 3. Cotoneastro nummulariae-Quercetum pubescentis quercetosum trojanae, 4. Cotoneastro nummulariae-Quercetum pubescentis typicum, 5. Astragaletum plumosomicrocephalii).

Slika 6: Analiza DCA rastlinskih združb preučevanega območja (1. Phragmites australis, 2. Pastinaco sativae-Populetum nigrae, 3. Cotoneastro nummulariae-Quercetum pubescentis quercetosum trojanae, 4. Cotoneastro nummulariae-Quercetum pubescentis typicum, 5. Astragaletum plumosomicrocephalii). 3: Cotoneastro nummulariae-Quercetum pubescentis quercetosum

Slika 7: Raznolikost rastlinskih združb preučevanega območja

(1: Phragmites australis, 2: Pastinaco sativae-Populetum nigrae, 3: Cotoneastro nummulariae-Quercetum pubescentis quercetosum trojanae, 4: Cotoneastro nummulariae-Quercetum pubescentis

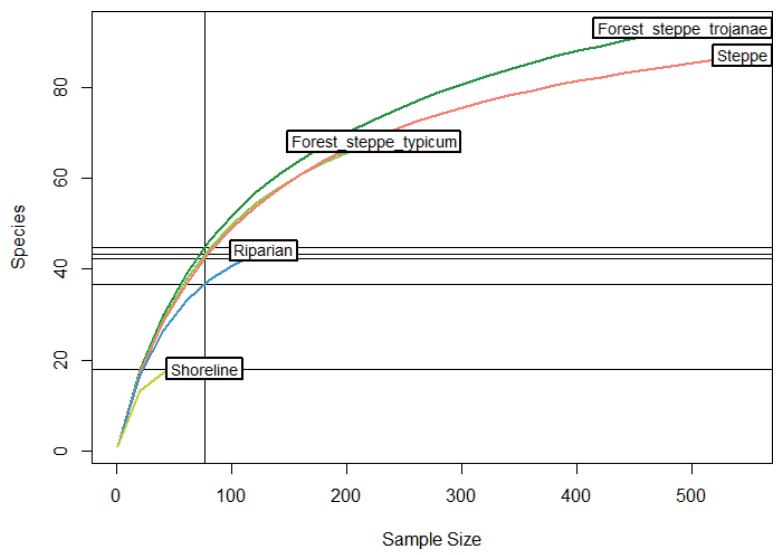

Figure 8: The sample-based rarefaction curve for species richness of the forest-steppe, steppe, riparian, and shoreline vegetation in the study area Slika 8: Krivulja kopičenja vrst za gozdno stepo, stepo, obrečno in obalno vegetacijo, nastala na osnovi vzorčenj. 


\section{Life forms and Chorology}

The ratio of Irano-Turanian elements (20\%) was higher in Cotoneastro nummulariae-Quercetum pubescentis followed by an equal rate of Euro-Sibirian (11\%) and Mediterranean elements $(11 \%)$. However, the ratio of Mediterranean elements (28\%) was equal to the Irano-Turanian (28\%) in Astragaletum plumoso-microcephalii. On the other hand, Pastinaco sativae-Populetum nigrae was dominated by Euro-Siberian elements (18\%) followed by IranoTuranian elements (5\%). In Phragmites australis community, Irano-Turanian (9\%) and Euro-Sibirian (8) elements were almost in the same rate.

According to life forms spectrum, therophytes (45\%) were higher in Phragmites australis community followed by cryptophytes (30\%). Rate of phanerophytes (36\%) were close to hemicryptophytes (35\%) in Pastinaco sativaePopuletum nigrae. Astragaletum plumoso-microcephalii was rich in terms of hemicryptophytes (43\%) and chamaphyte (26\%). The ratio of hemicryptophytes (45\%) was higher than chamaephytes (23\%) and phanerophytes (14\%) in Cotoneastero nummulariae-Quercetum pubescentis.

\section{Discussion}

\section{Syntaxonomy}

The general distribution of $A$. microcephalus was only reported in Caucasus and Iran in addition to Anatolia (Davis 1965-1985). The steppes dominated by A. microcephalus, which are in the oro-Mediterranean zone of the inner, southern, and eastern Anatolia, were classified under the class Astragalo-Brometea Quézel 1973. However, its borders around eastern Anatolia and Iran cannot be completely enlightened yet (Hamzaoğlu 2006; Noroozi et al. 2010). Astragaletum plumoso-microcephalii, which was determined as a new association, classified under the class Astragalo-Brometea and the order Onobrychido armeni-Thymetalia leucostomi comprising the steppe communities of Central Anatolian highlands. It occurs on non-saline, volcanic bedrock, and calcareous soils on steep slopes between $1650 \mathrm{~m}$ and $1800 \mathrm{~m}$ a.s.l. In the study area, $A$. microcephalus co-occurs with the characteristic species such as Astragalus plumosus and Allium paniculatum subsp. paniculatum. In addition, the species such as Thymus sipyleus, Festuca valesiaca and Taeniatherum caput-medusae subsp. crinitum, which are characteristics of Phlomido armeniacae-Astragalion microcephalii and Astragalo microcephali-Brometea tomentelli, were represented with a high cover values in the association. The Astragalus microcephalus associations in Anatolia, which have frequently dissimilar floristic composition, differ from each other in terms of ecological conditions such as soil, altitude, and slope (Hamzaoğlu et al. 2004; Hamzaoğlu 2005). For this reason, various Astragalus microcephalus associations were determined in Turkey (Hamzaoğlu 2005). When species composition of Astragaletum plumoso-microcephalii was compared with other $A$. microcephalus associations described in Anatolia, the highest similarities were found with Salvio wiedemanni-Astragaletum microcephali (35.8\%) and Centaureo deflexae-Astragaletum microcephali (31.34\%), respectively (Aydoğdu et al. 1994; Hamzaoğlu 2005). Although the dominant species of the associations is $A$. microcephalus, their characteristic species are quite different from each other. While Salvio wiedemanni-Astragaletum microcephali are described by the characteristics such as Salvia wiedemannii Boiss., Bunium microcarpum (Boiss.) Freyn subsp. bourgaei (Boiss.) Hedge \& Lamand, Thesium billardieri Boiss., Crucianella disticha Boiss., and Petrorhagia cretica (L.) Ball \& Heywood., Centaureo deflexae-Astragaletum microcephali are described with Centaurea deflexa Wagenitz and Verbascum cheiranthifolium Boiss. They are also classified in different alliances in the same order (Onobrychido armeni-Thymetalia leucostomi); while the former was included in Astragalo karamasici-Gypsophilion eriocalycis Ketenoğlu et al. 1983, the latter in Arenario ledebouriani - Astragalion plumose Akman 1990. In addition, they occur on different ecological conditions besides the floristic dissimilarity. The new association also has different site conditions (altitudinal range, soil, and main rock) compared to previously described ones. The former associations cannot rise up to 1100 m a.s.l., while Astragaletum plumoso-microcephalii occurs in the sub-alpine zone. The Centaureo deflexaeAstragaletum microcephali grows on gypsiferous soils and Salvio wiedemanni-Astragaletum microcephali also occurs on brown non-calcareous soils on granite main rock.

Thermophilous oak and conifer woodlands of semi-dry regions in Southern and Eastern Europe and Anatolia belong to the class Quercetea pubescentis (Oberd. 1948, Doing- Kraft 1955) Scamoni \& Passarge 1959. In Turkey, Central Anatolian forest-steppe communities were classified under the alliance Quercion anatolicae Akman, Barbéro, \& Quézel 1979 and the order Querco cerridisCarpinetalia orientalis Quézel, Barbéro, \& Akman 1980 of the above-mentioned class. Cotoneastro nummulariaeQuercetum pubescentis, which was firstly described in the study area, was classified under Quercion anatolicae, Querco cerridis-Carpinetalia orientalis, and Quercetea pubescentis. The species such as Securigera varia, Vicia cracca subsp. stenophylla, Trifolium elongatum, Clinopodium vulgare subsp. arundanum, and Lathrus digitatus, which are the characteristic species of the Quercion anatolicae and Querco cerridis-Carpinetalia orientalis, were frequently 
found as the understory of xeric oak forests in Central Anatolia. When we compare the xeric oak dominated forest-steppe associations in Central Anatolia in terms of floristic similarity, the new association was the most similar to the Rhamno oleoidis-Quercetum pubescentis (34.84\%) association described in the Melendiz Mountain in the southeast of Central Anatolia which is found in a similar altitudinal range. The second similar association $(30.82 \%)$ was Trifolio-Quercetum pubescentis which occurs in Soğuksu National Park in the northwest of Central Anatolia up to $1380 \mathrm{~m}$ a.s.l. (Adigüzel \& Vural 1995; Kenar \& Ketenoğlu 2016). Trifolio-Quercetum pubescentis was described with the characteristic species such as Vicia cracca subsp. stenophylla Vel., Lotus Aegeus (Griseb.) Boiss., Teucrium chamaedrys subsp. syspirense (K. Koch), Trifolium elongatum Willd., Muscari aucheri (Boiss.) Baker, Prunus divaricata Ledeb. subsp. divaricata, and Veronica multifida L., and Rhamno oleoidis-Quercetum pubescentis with Rhamnus lycioides subsp. oleoides (L.) Jahand. \& Maire, Phlomis nissolii L., Pilosella cymosa (L.) F.W. Schultz \& Sch. Bip., Inula montbretiana DC., Onobrychis oxyodonta Boiss., Pimpinella olivieroides Boiss. \& Hausskn., and Torilis ucranica Spreng. However, the new association includes totally different characteristic species which are Cotoneaster nummularius, Juniperus oxycedrus subsp. oxycedrus, and Phleum montanum. The herb layer of forest-steppes in Central Anatolia is rich in steppe species due to open forest canopy. The layer is also supported by forest-steppe specialists and this heterogeneity reveals the forest-steppe associations that have low floristic similarity. Moreover, some factors such as altitude and micro-topography may also play important role in dissimilarity of the communities. Interestingly, the Cotoneastro nummulariae-Quercetum pubescentis has the sub-association like Rhamno oleoidis-Quercetum pubescentis in Melendiz Mountain that is dominated by Quercus trojana. However, neither of the sub-associations include common characteristic species.

The riparian habitats serving as a bridge between terrestrial and aquatic ecosystems play an important role in transportation of nutrient, sediment, pollen, organic matter, organisms, and water (Naiman \& Decamps 1997). In this respect, riparian habitats are the most dynamic parts of the landscape. The species of Salix L., Populus L., and Tamarix L. species usually dominate the riparian vegetation. A riparian forest community dominated by Populus nigra was described in the study area. The new riparian association, Pastinaco sativae-Populetum nigrae, occurs on calcareous and non-saline soils with average phosphorous and organic matter content and low nitrogen amount. It extends towards the northwest and southeast of the riverbank in Narköy. The Pastinaco sativae-Populetum nigrae was classified under Populetalia albae Br.-Bl. ex Tchou 1949, Populion albae Br.-Bl. ex Tchou 1949 comprising Mediterranean and sub-Mediterranean riparian gallery forests of the class Alno glutinosae-Populetea albae that comprises generally riparian gallery forest in Euro-Siberian and Mediterranean region. Furthermore, the class encompasses azonal alluvial forests of Europe, North Africa, and the western regions of the Middle East, previously classified within the Querco-Fagetea Br.-Bl. et Vlieger in Vlieger 1937 without considering attitude of zonality or azonality (Mucina et al. 2016). Since there is a lack of information on riparian vegetation in Anatolia, any Populus nigra dominated association has not been reported in Turkey before. Therefore, this association is the first poplar-dominated riparian association described in Turkey. Only, two riparian associations dominated by Salix alba and Populus alba L. were described in the Porsuk River in Eskişehir province and Ihlara valley in Aksaray province in Turkey (Kaya \& Cansaran 2015, Özdeniz et al. 2016). Among these associations the highest floristic similarity (14.63\%) was found with Populetum albae in Porsuk River. Although both were classified in the same alliance, the floristic similarity is quite low. Populetum albae composed of species such as Crataegus monogyna Jacq. var. monogyna, Urtica dioica L., and Rosa canina L. with high frequencies. On the other hand, Pastinaco sativaePopuletum nigrae, which was described in the study area, is composed of characteristic species such as Pastinaca sativa L. subsp. urens (Req. Ex Gren. \& Godr.), Elaeagnus angustifolia L., Mentha longifolia subsp. thyphoides (Briq.) Harley. Also, Fraxinus angustifolia subsp. oxycarpa (Willd.) Franco \& Rocha Afonso and Phragmites australis (Cav.) Trin. ex Steud. is not found in the association as in Populetum albae. On the other hand, some Populus nigra dominated associations were described in Europe such as Ligustro-Populetum nigrae, Carduo crispi-Populetum nigrae, and Salici neotrichae-Populetum nigrae (Schnitzler 1996, Makra 2005, Costa et al. 2011, Poldini et al. 2011). The floristic similarity of Pastinaco sativae-Populetum nigrae with all these communities was quite low.

Phragmites australis community is distributed on the shoreline of Narligöl, which is intensely covered with $P$. australis, because this species shows high growth and reproduction success, and is a mono-dominant species. It usually prevents distribution of other species (Uddin \& Robinson 2017). Also, P. australis was considered as an important indicator of the accumulation of nutrient contents in water and it can be adapted to anaerobic conditions and soils with a $\mathrm{pH}$ range of 3.7 and 8.7 in eutrophic and mesotrophic water (Othman et al. 2014). That Phragmites communities are distributed around the lake and the fact that they are not present in the riparian area of the study area may indicate a higher nutrient accu- 
mulation in the water. In the study area, the community cannot be described at association level due to poor species composition. Although it includes some characteristic species of the class Phragmito-Magnocaricetea Klika in Klika \& Novák 1941 and the order Phragmitetalia Koch 1926, characteristic species are not sufficient to define a new association.

In brief, four vegetation types were determined including steppe, forest-steppe, riparian, and shoreline in the study area. Based on classification and analysis of floristic composition of the communities, we propose the following the syntaxonomical list:

Phragmito-Magnocaricetea Klika in Klika et Novak 1941 Unit 1: Phragmites australis (Cav.) Trin. ex Steudel community

Alno glutinosae-Populetea albae P. Fukarek et Fabijanić1968

Populetalia albae Br.-Bl. ex Tchou 1949

Populion albae Br.-Bl. ex Tchou 1949

Unit 2: Pastinaco sativae-Populetum nigrae ass. nov. hoc loco

Quercetea pubescentis (Oberd. 1948, Doing- Kraft 1955) Scamoni \& Passarge 1959

Querco cerridis-Carpinetalia orientalis Quézel, Barbéro \& Akman 1980

Quercion anatolicae Akman, Barbéro \& Quézel 1979

Cotoneastro nummulariae-Quercetum pubescentis ass. nov. hoc loco

Unit 3: quercetosum trojanae subass. nov. hoc loco

Unit 4: typicum subass. nov. hoc loco

Astragalo microcephali-Brometea tomentelli Quézel 1973

Onobrychido armenae-Thymetalia leucostomi Akman, Ketenoğlu \& Quézel 1985

Phlomido armeniacae-Astragalion microcepha-

lii Akman, Ketenoğlu, Quézel, Demirörs, 1984

Unit 5: Astragaletum plumoso-microcephalii ass. nov. hoc loco

\section{Ecology and plant diversity}

Vegetation types in the study area demonstrate clear differences in terms of ecological conditions. Increasing continental influence depending on altitude is very effective on steppe and forest-steppe vegetation. In addition, moisture and nutrient were the most important ecological factors on riparian and shoreline vegetation at lower altitudes. These differences were also showed by average indicator values for nutrient, moisture, and continental- ity. Average EIVs are more prominent among vegetation types than associations. However, calibration and assignment of indicator values pertaining to Central Anatolia may give better discriminations. Furthermore, it is observed that grazing density is the highest on steppe vegetation in the study area. The amount of humus in the soil is so low in the steppe which can be explained by heavy grazing (Dengler et al. 2012).

The forest-steppe and its sub-associations have the highest species diversity in the study area and the steppe association does not lag behind in plant diversity from the forest-steppe association, as well (Figure 8). Foreststeppes can be described as ecotones in which the environment often rapidly alters with regard to abiotic and biotic factors and the gene flow between populations is high and this lead to increase richness and abundance of the species. The forest-steppes can be thought a synthesis of two different habitats because the floristic composition of the forest-steppe in Central Anatolia is comprised of both steppe species and forest-steppe specialists. Even, the edges of forest-steppes can contain their own edge-related species besides the species in interior parts of forest-steppe and steppe (Bátori et al. 2018, Erdös et al. 2019). The plant diversity in steppe depends on various drivers, particularly such as soil types, geomorphology, and microclimate (Ambarlı et al. 2016). The lowest species diversity is in the Phragmites australis community. P. australis does not allow other species to occur in the shoreline because it effectively resists invasion. Moreover, habitat disturbances such as high evapotranspiration, eutrophication, and litter and sediment accumulation promote the expansion of P. australis (Robert 2016).

A semi-arid cold Mediterranean climate prevailing in the study area predominantly allows the development of steppe and forest-steppe vegetation. Steppe vegetation comprises many spiny cushion-like plants of hemicryptophytes, chamaephytes, and perennial graminoids adapted to harsh climate conditions (cold climate, low precipitation, and long dry season) (Djamali et al. 2012). Therophytes can also adapt to drought, shortage of precipitation and very dynamic ecosystems indicating anthropogenic factors such as grazing or pollution (Campos et al. 2004, Pantera et al. 2009, Bloch-Petersen et al. 2006). The dominance of hemicryptophytes and therophytes may indicate the adaptation of the plants to arid conditions in the study area that is also under humaninduced degradation. For instance, Phragmites australis community, which is under grazing degradation, was composed of many therophytes. The dominance of phanerophytes and cryptophytes in moist areas also shows that topography and microclimate are effective on the distribution of plant communities in some part of the study 
area. At higher altitudes, Iran-Turanian and Mediterranean elements often spread over open areas and steppes, whereas Euro-Siberian elements are distributed in humid areas and meadows. Therefore, the number of IranoTuranian elements, hemicryptophytes, and chamaephytes is higher in Astragaletum plumoso-microcephalii and Cotoneastro nummulariae-Quercetum pubescentis followed by Mediterranean elements. However, the number of EuroSiberian elements, phanerophyte, and hemicryptophyte was higher in Pastinaco sativae-Populetum nigrae riparian vegetation. Since steppe and forest-steppe vegetation covers most of the study area, Irano-Turanian elements are represented by a high proportion.

Widespread human-induced degradation and ongoing habitat loss resulted in steppes being one of the most threatened grassland types in the world (Török et al. 2016). Today, Anatolian steppes are facing serious problems such as overgrazing, soil erosion, intensive farming, and incorrect forestation practices (Conde et al. 2002). This excessive degradation on the steppe and forest-steppe vegetation with their prominent biodiversity stresses the need for their conservation and restoration (Erdős et al. 2018). A small part of the Anatolian Biogeographical Region $(1.5 \%)$ was defined as protected areas, but there is no comprehensive initiative to protect biodiversity for the remaining steppe areas (Ambarlı et al. 2016). The development and proper implementation of management programs such as the Rangeland Act and suitable afforestation plans should be the first step for the conservation of the Anatolian steppes. Further, these conservation efforts for steppes are considerably dependent on awareness of local people. Therefore, an integrative program providing collaboration among the government, local people, and scientists is required. Recently, the project of national and regional steppe conservation strategy supported by FAO/ GEF can be a good example for this type of integrative program (FAO 2016).

A feasible conservation attempt requires the knowledge on vegetation structure of forest-steppe regions. Indeed, as it was stressed by many authors, there is somewhat of a gap concerning steppe and forest-steppe vegetation of Central Anatolia due to the areas not yet surveyed. Although having covered a small area, the study makes a significant contribution to the understanding of Central Anatolian steppe, forest-steppe, and wetland vegetation, its structure, ecology, and species richness. This information will promote to the preparation of detailed vegetation maps and constitute core knowledge for management plans and conservation actions. Therefore, we believe that this vegetation study is valuable and an important stage to bring about an insight of vegetation change in Anatolia in the future.

\section{Acknowledgements}

This research was financially supported by Aksaray University, Scientific Research Projects Coordination Unit, Turkey [grant number 2016-036].

Nihal Kenar (D, https://orcid.org/0000-0001-7029-4241 Süleyman Çoban $\mathbb{D}$, https://orcid.org/0000-0003-15709795

\section{References}

Adıgüzel, N. \& Vural, M. 1995: The vegetation of Soğuksu National Park. Turkish Journal of Botany 19: 213-234 [in Turkish].

Akman, Y. \& Daget, P.H. 1971: Quelques aspects synoptiques des climats de la Turquie. Bull. Soc. Long. Georg. 5(3): 269-300.

Akman, Y. 1974: Etude phyto-ecologique de la region de Beypazar1Karaşar et Nallıhan. Communications De la Faculté Des Sciences De L'université D’Ankara 18: 81-99.

Akman, Y., Barbero, M. \& Quezel, P. 1978a: Contribution à l'étude de la végétation forestière d'Anatolie méditerranéenne. Phytocoenologia 5: 1-79.

Akman, Y., Barbero, M. \& Quezel, P. 1978b: Contribution à l'étude de la végétation forestière d'Anatolie méditerranéenne. Phytocoenologia 5: $186-276$.

Akman, Y., Barbero, M. \& Quezel, P. 1978c: Contribution à l'étude de la végétation forestière d'Anatolie méditerranéenne. Phytocoenologia 5: $277-346$

Akman, Y., Ketenoğlu, O., Quézel, P. \& Demirors, M. 1984: A syntaxonomic study of steppe vegetation in Central Anatolia. Phytocoenologia 12: 563-584.

Akman, Y. \& Aydoğdu, M. 1986: A phytosociological study in the vicinities of Çamlıdere, Çamkoru and Peçenek (Ankara). Communications De la Faculté Des Sciences De L'université D’Ankara 4: 9-24.

Akman, Y. 1990: Etude de la végétation steppique des montagnes d)Aydos située au Nord-Ouest d`Ankara. Ecologia mediterranea 16: 223-230.

Akman, Y., Quézel, P., Ketenoğlu, O. \& Kurt, L. 1993: Analysesyntaxinomique desforêts de Liquidambar orientalis en Turquie. Ecologia Mediterranea 19:49-57.

Akman, Y., Quézel, P., Aydoğdu, M., Ketenoğlu, O., Kurt, L., \& Evren, H. 1994: A phytosociological research on the steppe vegetation of the Yaprakli mountains (Çankiri, Turkey). Ecologia Mediterranea 20: 1-7.

Akman, Y., Vural, M., Quézel, P., Kurt, L., Ketenoğlu, O., Serin, M. \& Barbero, M. 1996: Etude de la végétation steppique de la région de Karaman et d'Ermenek (sud de l'Anatolie Centrale). Ecologia Mediterranea 22(3/4): 1-20. 
Ambarlı, D,. Zeydanlı, U.S., Balkız, Ö., Aslan, S., Karaçetin, E., Sözen, M., Ilgaz, Ç., Ergen, A.G., Lise, Y., Çağlayan, S.D., Welch, H.J., Welch, G., Turak, A.S., Bilgin, C.C., Özkil, A. \& Vural, M. 2016: An overview of biodiversity and conservation status of steppes of the Anatolian Biogeographical Region. Biodiversity and conservation 25: 2491-2519.

Atalay, I., Efe, R. \& Öztürk, M. 2014: Ecology and classification of forests in Turkey. Procedia-Social and Behavioral Sciences 120: 788-805.

Aydoğdu, M., Akman, Y., Quezel, P., Barbero, M., Ketenoğlu, O. \& Kurt, L. 1994: Syntaxonomic analysis of gypsaceous vegetation of the surrounding area between Ayaş-Polatlı and Beypazarı (Ankara, Turkey). Ecologia Mediterranea 20: 9-19.

Aydoğdu, M., Ketenoğlu, O. \& Hamzaoğlu, E. 1999: New syntaxa from Cappadocia (Kirşehir, Türkiye). Israel Journal of Plant Sciences 47(2): 123-129.

Aydoğdu, M., Kurt, L., Hamzaoğlu, E., Ketenoğlu, O. \& Cansaran, A. 2004: Phytosociological studies on salty steppe communities of Central Anatolia, Turkey. Israel Journal of Plant Sciences 52: 72-79.

Bátori, Z., Erdős, L., Kelemen, A., Deák, B., Valkó, O., Gallé, R. \& Tölgyesi, C. 2018: Diversity patterns in sandy foreststeppes: a comparative study from the western and central Palaearctic. Biodiversity and Conservation 27(4): 1011-1030.

Bilgin, R. 2011: Back to the suture: the distribution of intraspecific genetic diversity in and around Anatolia. International Journal of Molecular Sciences 12(6): 4080-4103.

Blasi C. \& Burrascano S. 2013: The role of plant sociology in the study and management of European forest ecosystems. iForest Biogeosciences and Forestry 6: 55-58.

Bloch-Petersen, M., Brandt, J. \& Olsen, M. 2006: Integration of European habitat monitoring based on plant life form composition as an indicator of environmental change and change in biodiversity. Geografisk Tidsskrift-Danish Journal of Geography 106: 61-74.

Braun-Blanquet, J. 1964: Pflanzensoziologie Grundzüge der Vegetationskunde (2nd edition). Springer Verlag, Wien, 866 pp.

Campos, J.A., Herrera, M., Biurrun, I. \& Loidi, J., 2004: The role of alien plants in the natural coastal vegetation in central northern Spain. Biodiversity and Conservation 13: 2275-2293.

Chiarucci, A., Bacaro, G., Rocchini, D., Ricotta, C., Palmer, M., \& Scheiner, S. 2009: Spatially constrained rarefaction: incorporating the autocorrelated structure of biological communities into sample-based rarefaction. Community Ecology 10(2): 209-214.

Conde, S., Richard, D., Leclere, A., Sotolargo, B. \& Pinborg, U. 2002: Biogeographical Regions in Europe: the Anatolian Region - the Biogeographical Transition to Asia (Report). European Environment Agency, Sweden.

Costa, J.C., Neto, C., Capelo, J., Lousã, M. \& Rivas-Martinez, S. 2011: A global view on the riparian forests with Salix neotricha and Populus alba in the Iberian Peninsula (Portugal and Spain). Plant Biosystems 145: 553-569.

Davis, P.H. 1965-1985: Flora of Turkey and the East Eagean Islands Vol 1-9. Edinburg University Press, Edinburgh.

Dengler, J., Chytrý, M. \& Ewald, J. 2008: Phytosociology. In: Jørgensen, S.E. \& Fath, B.D. (eds.): Encyclopedia of Ecology. Elsevier, Amsterdam, pp. 2767-2779.
Dengler, J., Becker, T., Ruprecht, E., Szabó, A., Becker, U., Beldean, M., Bita-Nicolae, C., Dolnik, C., Goia, I., Peryat, J., Sutcliffe, L.M., Turtureanu, P.D. \& Uğurlu, E., 2012: Festuco-Brometea communities of the Transylvanian Plateau (Romania), a preliminary overview on syntaxonomy, ecology, and biodiversity. Tuexenia 32: 319-359.

Dengler, J., Janišová, M., Török, P. \& Wellstein, C. 2014: Biodiversity of Palaearctic grasslands: a synthesis. Agriculture, Ecosystems \& Environment 182: 1-14.

Dizdar, M.Y. 2003: The land resources of Turkey. The Union of the Chambers of Turkish Engineers and Architects (TMMOB) Technical Publication Series, Ankara [in Turkish].

Djamali, M., Brewer, S., Breckle, S.W. \& Jackson, S.T. 2012: Climatic determinism in phytogeographic regionalization, a test from the Irano-Turanian region, SW and Central Asia. Flora, Morphology, Distribution, Functional Ecology of Plants 207: 237-249.

Ekim, T., Koyuncu, M., Vural, M., Duman, H., Aytac, Z. \& Adıgüzel, N. 2000: Türkiye Bitkileri Kırmızı Kitabı (Egrelti ve Tohumlu Bitkiler) Red Data Book of Turkish Plants (Pteridophyta and Spermatophyta). Nezahat Gökyiğit Botanic Garden (NGBB) and ANG Foundation and Flora Research Society, İstanbul, 1290 p.

Erdős, L., Ambarli, D., Anenkhonov, O.A., Bátori, Z., Cserhalmi, D., Kiss, M., Kröel-Dulay, G., Liu, H., Magnes, M., Molnár, Z. et al. 2018: The edge of two worlds: A new review and synthesis on Eurasian forest-steppes. Applied Vegetation Science 21: 345-362.

Erdős, L., Krstonošić, D., Kiss, P. J., Bátori, Z., Tölgyesi, C. \& Škvorc, Ž. 2019: Plant composition and diversity at edges in a semi-natural forest-grassland mosaic. Plant Ecology 220(3): 279-292.

Food and Agriculture Organization (FAO), 2016: Conservation and Sustainable Management of Turkey's Steppe Ecosystems Retrieved July 25, 2019 from https://www.thegef.org/sites/default/files/project_ documents/Project_Doc_0.pdf

Gotelli, N.J. \& Colwell, R.K. 2011: Estimating species richness. Biological Diversity: Frontiers in Measurement and Assessment 12: 39-54.

Guntenspergen, G.R., Stearns, F. \& Kadlec, J.A. 1989: Wetland vegetation. In: Hammer D.A (ed.): Constructed wetlands for wastewater treatment: municipal, industrial and agricultural. CRC Press, USA, PP. 73-88.

Güner, A., Aslan, S., Ekim, T., Vural, M. \& Babaç, M.T. (eds.) 2012: Checklist of Vascular Plants of Turkey. Nezahat Gökyiğit Botanik Bahçesi ve Flora Araştırmaları Derneği Yayını, İstanbul, 1290 p. [in Turkish].

Hamzaoğlu, E., Aydoğdu, M., Kurt, L., \& Cansaran, A. 2004: New syntaxa from the west part of Central Anatolia. Pakistan Journal of Botany 36(2): 235-246.

Hamzaoğlu, E. 2005: The steppe vegetation of Dinek Mountain (Kırıkkale). Gazi University Journal of Science 18: 1-15.

Hamzaoğlu, E. 2006: Phytosociological studies on the steppe communities of East Anatolia. Ekoloji 15: 29-55.

Hennekens, S.M. \& Schaminée J.H. 2001: TURBOVEG, a comprehensive data base management system for vegetation data. Journal of Vegetation Science 12: 589-591.

Hill, M.O. 1979: TWINSPAN a fortran program for arranging multivariate data in an ordered two-way table by classification of the individuals and attributes. Cornell University, New York, 90 pp. 
Jackson, M.L. 1958: Soil chemical analysis. Prentice Hall Inc, Englewood Cliffs, New Jersey.

Karaömerlioglu, D. 2007: Plant ecology investigation of natural ecosystems in the Göksu delta (Silifke).Doctoral dissertation, Institute of Natural and Applied Sciences, The University of Cukurova, Turkey, 315 pp.

Kavgaci, A., Čarni, A., Tecimen, H., \& Özalp, G. 2011: Diversity of floodplain forests in the Igneada region (NW Thrace - Turkey). Hacquetia 10(1): 73-93.

Kaya, Z., \& Raynal, D.J. 2001: Biodiversity and conservation of Turkish forests. Biological Conservation 97(2): 131-141.

Kaya, Ö.F. \& Cansaran A. 2015: Phytosociological examination of Ihlara Special Environmental Conservation Zone. Applied Ecology and Environmental Research 14: 13-35.

Kenar, N. \& Ketenoğlu, O. 2016: The phytosociology of Melendiz Mountain in the Cappadocian part of Central Anatolia (Niğde, Turkey). Phytocoenologia 46: 141-183.

Ketenoğlu, O., Kurt, L., Akman, Y., \& Serin, M. 1996: A new alliance from Central Anatolia.,"Minuartion Juniperino-pestalozzae". Turkish Journal of Botany 20: 457-464

Ketenoğlu, O., Tug, G.N., Bingöl, U., Geven, F., Kurt, L. \& Güney, K. 2010: Synopsis of syntaxonomy of Turkish forests. Journal of Environmental Biology 31: 71-80.

Kjeldahl, J. 1883: A new method for the determination of nitrogen in organic matter. Zeitschrift fur Analytische Chemie Fresenius 22: $366-382$

Koellner, T., Hersperger, A. M. \& Wohlgemuth, T. 2004: Rarefaction method for assessing plant species diversity on a regional scale. Ecography 27(4): 532-544.

Korkmaz, H., Mumcu, Ü., Alkan, S. \& Kutbay, H.G. 2012: Gölardı (Terme/Samsun) Yaban Hayatı Koruma Alanı'nın Psammofil, Higrofil ve Orman Vejetasyonu Üzerine Sintaksonomik Bir Araştırma. Ekoloji 21(85): 64-79.

Kurt, L., Tuğ, G.N. \& Ketenoğlu, O. 2006: Synoptic view of the steppe vegetation of central Anatolia. Asian Journal of PlantSciences 5: 733-739.

Kutbay, H.G., Kilinç, M. \& Kandemir, A. 1998: Phytosociological and ecological structure of Fraxinus angustifolia subsp. oxycarpa forests in the central Black Sea region. Turkish Journal of Botany 22(3): 157-162.

Kürschner, H. \& Parolly, G. 2012: The Central Anatolian Steppe. In: Marinus, M.J.A. \& Van Staalduinen, M.A. (eds.): Eurasian Steppes: Ecological problems and livelihoods in a changing world. Springer, Netherlands, pp. 149-171.

Langbein, W.B. 1961: Salinity and hydrology of closed lakes. US Government Printing Offic No. 412, Washington, 20 pp.

Naiman, R.J. \& Decamps, H. 1997: The ecology of interfaces: riparian zones. Annual review of Ecology and Systematics 28(1): 621-658.

Makra, O. 2005: Checklist of the associations of the Hungarian section of Tisza basin. Tiscia 35: 9-16.

McCune, B. 2007: Improved estimates of incident radiation and heat load using non-parametric regression against topographic variables. Journal of Vegetation Science 18: 751-754.
MGM, 2017: Meteorological data of Aksaray province. Retrieved April 10, 2017 from https://www.mgm.gov.tr/veridegerlendirme/il-veilceler-istatistik.aspx?m=AKSARAY

Mucina, L., Bültmann, H., Dierßen, K., Theurillat, J.P., Raus, T., Čarni, A. \& Chytrý, M. 2016: Vegetation of Europe, Hierarchical floristic classification system of vascular plant, bryophyte, lichen, and algal communities. Applied Vegetation Science 19: 3-264.

Noroozi, J., Akhani, H. \& Willner, W. 2010: Phytosociological and ecological study of the high alpine vegetation of Tuchal Mountains (Central Alborz, Iran). Phytocoenologia 40: 293-321.

Oksanen, J., Blanchet, F.G., Kindt, R., Legendre, P., Minchin, P.R., O'Hara, R.B., Simpson, G.L., Solymos, P., Stevens, M.H.H. \& Wagner, H., 2015: vegan: community ecology package. R package version $2.3-0$.

Olsen, S.R., Cole, C.V., Watanabe, F.S. \& Dean, L.A. 1954: Estimation of available phosphorus in soils by extraction with sodium bicarbonate. United States Department of Agriculture Circular 939, Washington DC, $19 \mathrm{pp}$.

Othman, R., Hanifah, N.A.B., Ramya, R., Ayuni, F., Hatta, B.M. \& Sulaiman, W.S.H.B. W. 2014: Aquatic Plants as Ecological Indicator for Urban Lakes Eutrophication Status and Indices. International Journal of Sustainable Energy and Environmental Research 3(4): 178-184.

Özdeniz, E., Kurt, L. \& Bergmeier, E. 2016: Syntaxonomical analysis of the riparian vegetation of the Porsuk River (Eskişehir-Kütahya/ Turkey). Turkish Journal of Botany 41: 609-619.

Pantera, A., Papadopoulos, A.M., Fotiadis, G. \& Papanastasis, V.P. 2008: Distribution and phytogeographical analysis of Quercus ithaburensis subsp. macrolepis in Greece. Ecologia mediterranea 34: 73-82.

Pasta, S., de Rigo, D. \& Caudullo, G. 2016: Quercus pubescens in Europe: Distribution, habitat, usage and threats. In: San-MiguelAyanz, J., de Rigo. D., Caudullo, G., Houston Durrant, T. \& Mauri, A. (eds.): European atlas of forest tree species. Publications Office of the European Union, Luxembourg, pp. 156-157.

Pignatti S. 2005: Valori di bioindicazione delle piante vascolari della flora d'Italia. Braun-Blanquetia 39: 1-97.

Poldini, L., Vidali, M. \& Ganis, P. 2011: Riparian Salix alba, Scrubs of the Po lowland (N-Italy) from a European perspective. Plant Biosystems 145: 132-147.

Quézel, P., Barbero, M. \& Akman, Y. 1978: L’Interpretation phytosociologique des groupements forestiers dans le Bassin Mediterraneen Oriental. Documents phytosociologiques 2: 329-352.

R Core Team, 2013: R: A language and environment for statistical computing. R Foundation for Statistical Computing, Vienna, Austria. http://www.R-project.org/(accessed 18 April 2018).

Richards, L.A. 1954: Diagnosis and improvement of saline and alkali soils. U.S. Department of Agriculture Handbook No 60, Washington DC, 160 pp.

Roberts, T.N. 2016: Alternate states of Phragmites australis (common reed) communities in an endangered wetland of southern Australia. Doctoral dissertation, Department of Ecology \& Environmental Science, The University of Adelaide, Australia, 74 pp.

Schnitzler, A. 1996: Comparison of landscape diversity in forests of the upper Rhine and the middle Loire floodplains (France). Biodiversity and Conservation 5: 743-758. 
Seçmen, Ö. \& Leblebici, E. 1996: The vegetation cover of Marmara region wetlands. Turkish Journal of Botany 20(2): 171-189.

Seçmen, Ö. \& Leblebici, E. 1997: The plants and vegetation of wetlands in Turkey. Ege Universitesi Fen Fakultesi Yayinlari No 158, İzmir, 800 pp. [in Turkish].

Schwinning, S. \& Sala, O.E. 2004: Hierarchy of responses to resource pulses in arid and semi-arid ecosystems. Oecologia 141(2): 211-220.

Sørensen, T. 1948: A method of establishing groups of equal amplitude in a plant society based on similarity of species content and its application to analyses of the vegetation on Danish commons. Vidensk Selsk Biol Skr 5:1-34.

Şekercioğlu, Ç.H., Anderson, S., Akçay, E., Bilgin, R., Can, Ö.E., Semiz, G., Tavşanoğlu, Ç., Yokeş, M.B., Soyumert, A., İekdal,

K., Sağlam, İK., Yücel, M., Dalfes, H.N. 2011: Turkey’s globally important biodiversity in crisis. Biological Conservation 144:

2752-2769.

Tavşanoğlu, Ç. 2017: Anadolu Bozkır Ekosistemleri Üzerinde İşleyen Müdahale Rejimleri. Kebikec: Insan Bilimleri Icin Kaynak Arastirmal Dergisi 43: 259-288.

Ter Braak, C.J. \& Smilauer, P. 2002: CANOCO reference manual and CanoDraw for Windows user's guide, software for canonical community ordination (version 4.5). Retrieved April 12, 2017 from $\mathrm{http} / /$ www.canoco.com

Tichý, L. 2002: JUICE, software for vegetation classification. Journal of vegetation science 13(3): 451-453.
Török, P., Ambarlı, D., Kamp, J., Wesche, K. \& Dengler, J. 2016: Step (pe) up! Raising the profile of the Palaearctic natural grasslands. Biodiversity and Conservation 25: 2187-2195.

Uddin, M.N. \& Robinson, R.W. 2017: Changes associated with Phragmites australis invasion in plant community and soil properties, A study on three invaded communities in a wetland, Victoria, Australia. Limnologica 66: 24-30.

Uğurlu, E., Roleček, J. \& Bergmeier, E. 2012: Oak woodland vegetation of Turkey-a first overview based on multivariate statistics. Applied Vegetation Science 15: 590-608.

Walkley, A. \& Black, I.A. 1934: An examination of the Degtjareff method for determining soil organic matter, and a proposed modification of the chromic acid titration method. Soil Science 37: 29-38.

Weber, H.E., Moravec, J. \& Theurillat, J.P. 2000: International Code of Phytosociological Nomenclature (3rd edition). Journal of Vegetation Science 11: 739-768.

Yurdakulol, E., Aydoğdu, M. \& Çetin, B. 1990: Kırıkkale-KalecikKırşehir arası step vejetasyonunun bitki sosyolojisi yönünden araștırılması. Doğa-Turkish Journal of Botany 14: 215-234.

Zohary, M. 1973: Geobotanical Foundations of the Middle East. Stuttgart (Germany). Gustav Fischer-Verlag. Stuttgart. 